
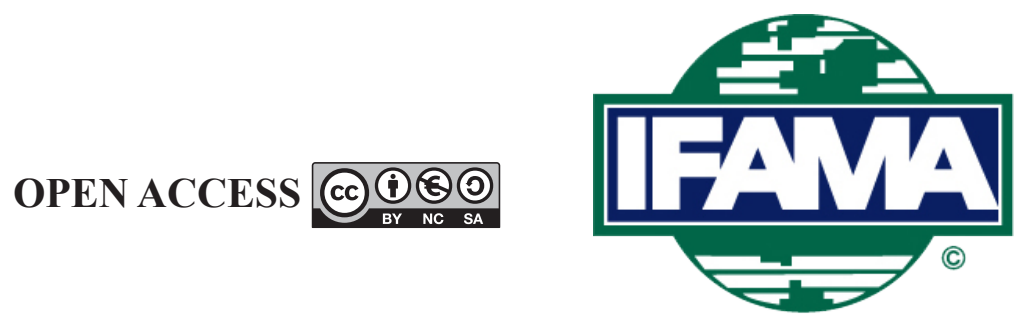

International Food and Agribusiness Management Review

Volume 24, Issue 3, 2021; DOI: 10.22434/IFAMR2020.0068

Received: 6 May 2020 / Accepted: 20 November 2020

\title{
Measuring consumer acceptance of instant fortified millet products using affective tests and auctions in Dakar, Senegal \\ RESEARCH ARTICLE
}

\author{
Hugo De Groote ${ }^{\oplus a}$, Bernard Munyua ${ }^{b}$, Djibril Traore ${ }^{\mathrm{c}}$, John R.N. Taylor ${ }^{\mathrm{d}}$, Mario Ferruzzi ${ }^{\mathrm{e}}$, \\ Cheikh Ndiaye ${ }^{f}$, Isiguzoro O. Onyeoziris and Bruce R. Hamaker ${ }^{\mathrm{h}}$ \\ ${ }^{a}$ Principal Scientist, ${ }^{b}$ Research Associate, International Maize and Wheat \\ Improvement Center (CIMMYT), P.O. Box 1041-00621, Nairobi, Kenya \\ ${ }^{c}$ Nutritionist, ${ }^{f}$ Food Technologist, Institut de Technologie Alimentaire, \\ Route des Pères Maristes, Hann Dakar, BP 2765, Sénégal \\ ${ }^{d}$ Professor, ${ }^{g}$ Research Associate, Institute for Food, Nutrition and Well-being, Department of Consumer \\ and Food Science, University of Pretoria, Pretoria, Private bag X20 Hatfield 0028, South Africa \\ eProfessor, Plants for Human Health Institute, North Carolina State \\ University, 600 Laureate Way, Kannapolis, NC 28081, USA \\ ${ }^{h}$ Professor, Department of Food Science, Purdue University, \\ 745 Agriculture Mall Drive, West Lafayette, IN 47907, USA
}

\begin{abstract}
Small-scale affordable extruders create new opportunities for small enterprise food processors to manufacture nutritionally enhanced products. Still, consumer interest in these products needs to be assessed first. Affective tests with 296 consumers in Dakar, Senegal, evaluated five pearl millet flours: (a) conventional, compared to four instant-porridge flour products; (b) sifted; (c) wholegrain; (d) sifted with premix; (e) wholegrain with micronutrient premix and food-to-food fortified (FtFF). Willingness-to-pay (WTP) was elicited through experimental auctions under two treatments: firstly without information, then with information. Consumers liked FtFF (taste, aroma, appearance) but were indifferent to instant. They did not appreciate wholegrain flour (appearance) or premix (appearance, aroma and taste). Without information, consumers showed no differences in WTP. With information, consumers paid premiums for FtFF (27-30\%) (both treatments), and premix (17\%), instant (9\%), and wholegrain (-10\%) (one treatment). Costs of instant, wholegrain and premix products were lower than consumers' WTP, indicating potential profits, but not those of FtFF. There is a market for instant cereals in Senegal. Consumers require product information in order to compromise on some attributes to benefit from instant, fortified and wholegrain pearl millet products. Manufacture would be cost-effective, but FtFF costs need to be reduced.
\end{abstract}

Keywords: extrusion, consumers, instant, food-to-food fortification, willingness-to-pay JEL code: D12, I12, L66

${ }^{\circledR}$ Corresponding author: h.degroote@cgiar.org 


\section{Introduction}

Cereals are major food staples in many African countries, where food-processing industries are emerging fast (Taylor et al., 2010). Rice and pearl millet are particularly important in Senegal (FAOSTAT, 2016), while maize is the most important cereal in most of East and Southern Africa including Kenya (De Groote and Kimenju, 2012). Millet is cultivated on one million hectares in Senegal; it is a drought-tolerant crop that is well suited to the Sahelian climate. Pearl millet is a particularly nutritious cereal as it is high in calcium, iron, essential fatty acids and in protein of reasonable quality (Taylor and Awika, 2017). In Senegal, it is mainly consumed as a porridge, and as well as being a basic staple, it is also used to fight fatigue, is given to the sick to generate energy and appetite, and is prepared during various family and religious celebrations (Dong, 2011). Improving the nutritional value of cereal products and the bio-accessibility of important nutrients such as iron, zinc and vitamin A in these products is an important concern for developing countries, where both rural and urban populations rely heavily on these cereals for their daily dietary nutrition. The improved food products could alleviate micronutrient deficiencies for the general population as well as for those at risk of nutrient deficiency (Cheikh, 2018).

One of the projects working on alleviation of micronutrient deficiencies is the Food Processing and PostHarvest Handling Innovation Lab (FPL) project that aims to sustainably reduce post-harvest losses, link farmers to markets, increase marketing opportunities, and increase and diversify food-processing markets for cereal and legume products (for more details on the project, see https://ag.purdue.edu/ipia/fpl/Pages/default. aspx). The project hopes to achieve these goals through innovations that reduce post-harvest losses, such as improved drying and storage methods, including using hermetic containers and low-cost grain-moisture meters to help farmers measure accurately the moisture level of the grain before storage, and, finally, through the introduction of a sustainable market-driven model for nutritionally enhanced foods.

Research activities of the project focus on the improvement of existing technologies and products, as well as the development of new ones. One of the processing technologies that the project is applying and evaluating is high temperature/short time (HTST) extrusion cooking to produce ready-to-eat (RTE) instant cereal products, fortified with micronutrient-rich ingredients from both commercial sources (premix) and from food plant sources (food-to-food fortification). Through innovative mechanisms for dissemination, these activities will improve quality, safety, and nutritional options for consumers, leading to increased market opportunities for producers.

One of the innovations are new, low-cost extrusion cookers allow small enterprises to enter the market for processed cereal products, including instant, fortified and flavored mixes (De Groote et al., 2018a). The process has many advantages, as it combines several operations such as preparation, formulation, pre-cooking, and fortification simultaneously for the producer, and offers savings in time and energy and improved quality for the consumer.

Within the FPL project, a team of food scientists from the Institut de Technologie Alimentaire (ITA), (Dakar), Purdue University (US), North Carolina State University, the University of Pretoria, and economists from the International Maize and Wheat Improvement Centre (CIMMYT), Nairobi collaborated to develop new, extruded, millet-based, decorticated, and whole meal instant products. These products were designed to enhance the availability as well as the uptake of micronutrients, and to supply $25 \%$ of the recommended daily allowance (RDA) of iron, zinc and vitamin A, through a dose of $120 \mathrm{mg}$ per $50 \mathrm{~g}$ of finished porridge. ${ }^{1}$

HTST-extrusion-cooking technology has been used extensively in the production of RTE cereal snacks due to its ease of operation and ability to produce a variety of textures and shapes which appeal to consumers (Brennan et al., 2013). Extrusion cooking is preferable to other food-processing techniques, as it is a continuous process with high productivity and significant nutrient retention, owing to the high temperature and short time

\footnotetext{
${ }^{1}$ The RDA of a nutrient is the estimated amount per day necessary for the maintenance of good health.
} 
required (Guy, 2001). It is particularly useful for manufacturing RTE products that have the same sensory and functional properties of traditional cereal-based foods. In Mexico, for example, optimized, extruded maize flour (EMF) from quality protein maize (QPM) was shown to have similar physio-chemical and functional characteristics to commercial nixtamalized maize flour (Reyes-Moreno et al., 2003). The technology can also be used to develop food products with higher nutritional quality, such as breakfast cereals that contain soy (Yeu, Lee, and Lee 2008). Recently, extrusion cooking combined with micronization (infrared treatment) has been shown to improve the protein-, micronutrient- and functional quality of a ready-to-eat, sorghumcowpea African porridge for young children (Vilakati et al., 2015). Purdue University has developed a mini single-screw extruder that is much less expensive than standard industrial models, which can process approximately $35 \mathrm{~kg}$ of grain per hour, at an energy cost of approximately $3.4 \mathrm{kWh}$ (Dr. Sanjeev Agarwal, Technochem International, Inc., Personal Communication; Technocheminc.com), making it suitable for small and medium enterprises in developing countries. This technology, therefore, has the potential to benefit the resource-poor in urban and rural areas who depend on these staple foods.

Producers of such new products in developing countries face several challenges. First, consumers have to accept the products and prefer them to the conventional products that are well-established and readily available in the market. Second, the cost of the new products is typically higher than the cost of the conventional products, but the new products need to remain competitive in the target market and for the targeted demographic groups. Therefore, before engaging in the production and marketing of extruded food, it is important that consumers' interests and preferences are properly assessed, in particular in the target population, low- and medium income consumers.

Focus group discussions conducted in both project countries, Senegal and Kenya, indicated a strong interest in affordable instant cereals among medium-income women, since the products were of high nutritional value, affordable, and saved time and energy when preparing the instant meals at home (De Groote et al., 2018a, 2020).

The products studied here make use of food-to-food fortification, an emerging food-based strategy that can complement current strategies in the ongoing fight against micronutrient deficiencies and that has the potential to address multiple micronutrient deficiencies simultaneously, with little dietary change required by consumers (Kruger et al., 2020). It is a component of food-based strategies, which promote the production, access, and intake of micronutrient rich foods with the aim of enhancing the content and/or bioavailability of target nutrients, especially micronutrients (Ruel, 2001). Studies of consumer acceptance of food-to-food fortification products have gained increasing attention, not only in the food sciences but also in the economics literature. In food sciences, these studies take the form of sensory evaluation, captured usually through hedonic rating, while in economics, they take the form of consumer valuation captured as willingness-to-pay for a product or its attributes (Birol and Bouis, 2019). In Africa, consumer studies on food made from biofortified crops include acceptance of bio-fortified maize in South Africa (Amod et al., 2016), orange-fleshed sweet potatoes in Tanzania (Tomlins et al., 2007), and quality protein maize in East Africa (De Groote et al., 2014). Further, CIMMYT and its partners have expanded this work on consumer acceptance of biofortified food crops, and now combine affective tests (with representative consumers, not a trained panel as in sensory evaluations) and the Becker-DeGroot-Marschak (BDM) mechanism in particular, on proVA biofortified maize in Ghana (De Groote et al., 2010b), and on QPM in Tanzania (De Groote et al., 2010b) and Ethiopia (Gunaratna et al., 2016). In this study, we build upon the previous work, to help the development of instant food-to-food fortification products that are acceptable by consumers, for both their sensory characteristics and their price, and that can be produced by local entrepreneurs with a reasonable profit margin.

The following were therefore the objectives of this study: (1) to assess consumer acceptance of the new, instant cereal products through affective tests; (2) to estimate consumers' WTP for the different traits tested: sifted cereal, whole grain cereal, instant cereal, and cereal with added micronutrients from premix or from other nutrient-rich foods (food-to-food fortification); (3) to estimate the effect of information about the 
product content on WTP; and (4) to evaluate the effect of socioeconomic characteristics on WTP for the various product attributes.

\section{Methods}

\subsection{Overview}

Two methods are commonly used to assess consumers' interest in new food products: affective tests and experimental auctions. Affective tests involve sensory evaluation of the new products by representative consumers, in contrast to trained panels (Meilgaard et al., 2007). Experimental auctions are a popular method of eliciting consumers' willingness-to-pay for new food products (Morawetz et al., 2011; Umberger and Feuz, 2004). Different types of auctions can be used, and a study in Ghana compared BDM, $\mathrm{n}^{\text {th }}$-price auction and choice experiments to elicit the WTP for a ProVA-rich new maize variety in Ghana (Banerji et al., 2018). Recent studies have combined affective tests and experimental auctions to obtain both consumers' evaluation, and WTP estimates for instant pearl millet products in Touba, Senegal (De Groote et al., 2018b) and instant maize products in Kenya (De Groote et al., 2020).

In this study, 296 consumers participated, both men and women, and all from Dakar, Senegal. They tasted and evaluated porridge made from instant and fortified pearl millet flour, produced using a mini extrusion cooker, in comparison to plain, conventional sifted pearl millet porridge. The evaluation was for all major sensory characteristics: appearance, aroma, taste and texture, as well as overall. The main product traits under evaluation were instant versus conventionally cooked cereal; sifted vs whole flour; and fortification with a commercial premix vs food-to-food fortification.

Participants received a show-up fee of 7,000 FCFA (US\$ $1=600$ FCFA at the time of the study). They were asked some socioeconomic questions, followed by affective tests with cooked products to determine consumers' acceptance, and finally they participated in the economic experiment to determine their willingness-to-pay (WTP) for the packed, finished products (flours) (Figure 1). To estimate the effect of information about the content of the products on WTP, the auctions were conducted both with and without that information (Figure 1).

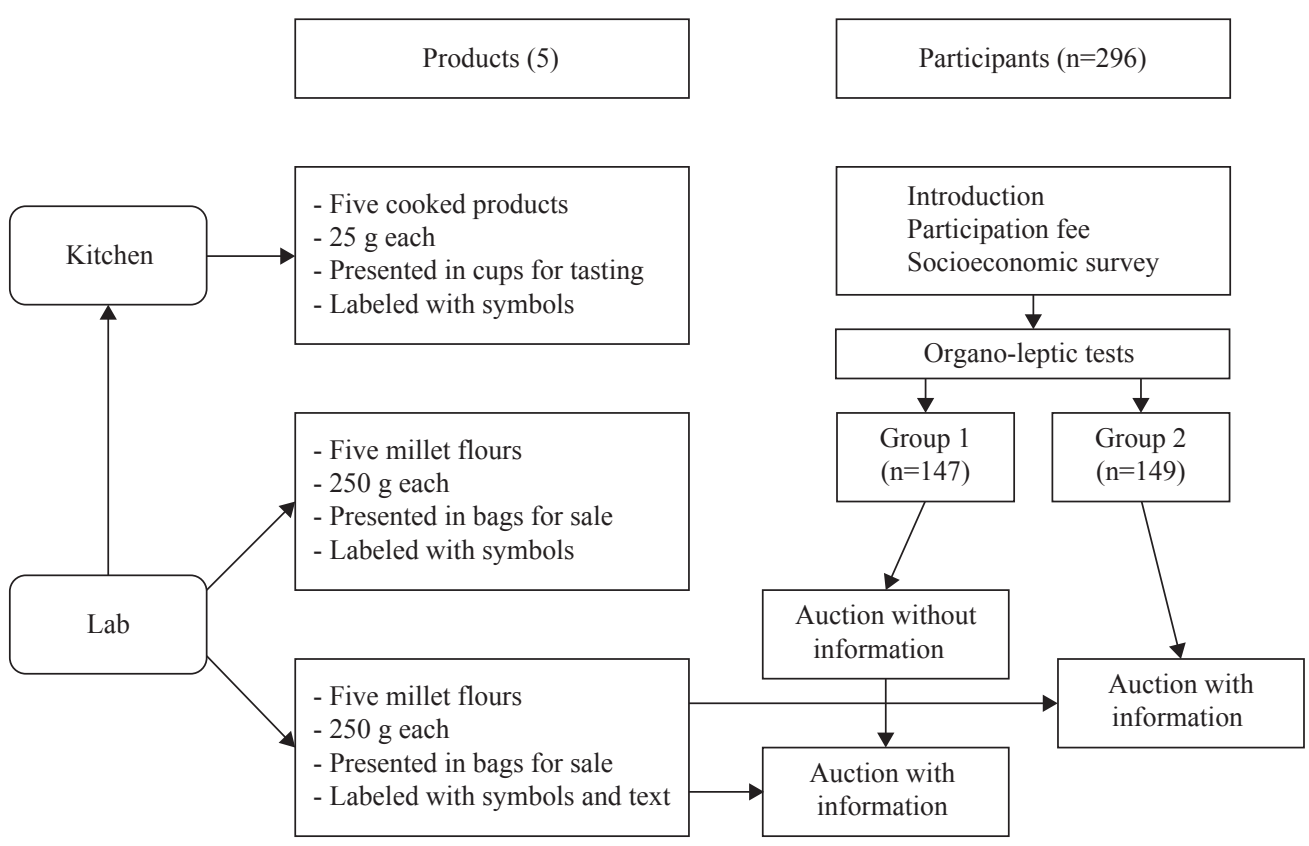

Figure 1. Study design. 


\subsection{The products}

To attain the research objectives, the traits of interest were carefully distributed over five different products, all made from pearl millet, chosen because it is the major cereal in Senegal (Figure 2). The base product was (A) traditional porridge made from decorticated millet, against which these new products were compared: (B) instant porridge from decorticated millet; (C) instant porridge from whole grain millet; (D) instant porridge from decorticated millet fortified with a commercial premix of minerals and vitamins; (E) instant porridge from whole grain millet, enhanced with food-to-food fortification (a blend of baobab and carrot combined with the commercial premix to deliver the equivalent vitamin A and iron level) (Table 1). The instant porridges were $33 \%$ solids, so it was assumed that a $0.25 \%$ dose of premix would deliver $\sim 30-40 \%$ RDA per $100 \mathrm{~g}$ of finished product. The chemical format of iron in the premix was ethylenediamine tetra acetic acid (EDTA) and ferrous sulfate, as the EDTA formulation increases the absorption of iron to about twice that of ferrous sulfate alone (Layrisse and MartInez-Torres, 1977). However, this formulation also gives the product a dark appearance when reconstituted. The addition of dried carrot and baobab in product E was intended to improve the product profile and enhance the micronutrients contained in these foods using local, recognized ingredients.

Training was given to the food technicians prior to the experiment on how to cook the conventional porridge properly, and how to reconstitute the instant porridge. The conventional porridge took 15 minutes to fully cook. The instant products B to E were reconstituted by adding $100 \mathrm{~g}$ of instant product to $200 \mathrm{ml}$ of boiling water while stirring continuously. The porridge was let to simmer for two minutes for microbial safety.

\subsection{Selection of site and participants}

The capital Dakar was selected to represent an urban setting and to contrast with a previous study in the city of Touba (De Groote et al., 2018a), which is located up-country and is to a large extent rural, and therefore presented a different demographic profile with respect to economic activities, income and education. For this study, participants were invited from five suburbs in Dakar; recruiters were sent to each of the selected suburbs with loudspeakers to announce the study and invite the general public to come to ITA at a specific day and time. The study took place from 28 February to 3 March 2017. Everyone who showed up was allowed to participate, and an average of 70 consumers per day took part in the study over four consecutive days.

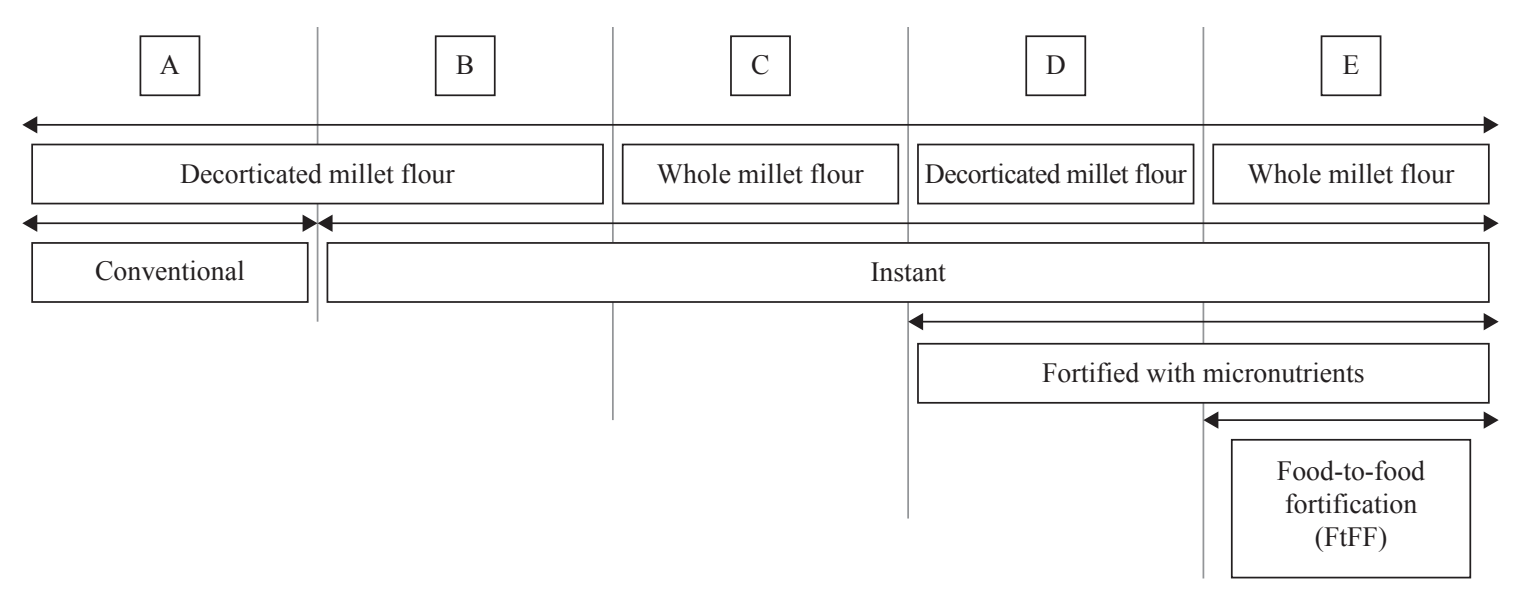

Figure 2. Product codes and the content of the different products. 
Table 1. The composition of products and nutritional information. ${ }^{1}$

\begin{tabular}{|c|c|c|c|c|c|c|c|c|c|}
\hline Code & Product name & $\begin{array}{l}\text { Pearl } \\
\text { millet }\end{array}$ & $\begin{array}{l}\text { Premix (iron } \\
\text { and vitamin } \\
\text { A palmitate, } \\
\text { target 20-40\% } \\
\text { RDA) }\end{array}$ & $\begin{array}{l}\text { Carrot } \\
\text { flour (for } \\
\text { vitamin A) }\end{array}$ & $\begin{array}{l}\text { Baobab } \\
\text { flour (for } \\
\text { iron) }\end{array}$ & Instant & Sifted & Whole & Symbol \\
\hline A & $\begin{array}{l}\text { Decorticated millet } \\
\text { (conventional) }\end{array}$ & 100 & & & & & $\mathrm{X}$ & & Open rectangle \\
\hline B & $\begin{array}{l}\text { Decorticated instant } \\
\text { millet }\end{array}$ & 100 & & & & $\mathrm{X}$ & $\mathrm{X}$ & & Open triangle \\
\hline $\mathrm{C}$ & $\begin{array}{l}\text { Whole grain instant } \\
\text { millet }\end{array}$ & 100 & & & & $\mathrm{X}$ & & $\mathrm{X}$ & Closed circle \\
\hline D & $\begin{array}{l}\text { Decorticated instant } \\
\text { millet fortified with } \\
\text { commercial premix }\end{array}$ & 99.75 & 0.25 & & & $\mathrm{X}$ & $\mathrm{X}$ & & Open circle \\
\hline $\mathrm{E}$ & $\begin{array}{l}\text { Whole grain instant } \\
\text { millet fortified with both } \\
\text { commercial premix and } \\
\text { food-to-food fortification }\end{array}$ & 79.9 & 0.1 & 10 & 10 & $\mathrm{X}$ & & $\mathrm{X}$ & Diamond \\
\hline
\end{tabular}

\subsection{Show-up fee, informed consent and socioeconomic survey}

Participants were individually welcomed and presented with a small show-up fee of 7,000 FCFA to express our gratitude, help with transport fees, and to ensure that they had cash to participate in the auction experiment. The amount was set at roughly twice the estimated average WTP for the products, estimated at 1000 FCFA, plus a small transport allowance of 6,000 FCFA (US\$ 10) as the tests and auctions were conducted at a central location, namely the ITA labs.

The planned activities of the day were then explained by one of six enumerators to the participants, who were assured that they could stop and leave at any time, and asked to give their informed consent. The enumerator signed the form as a witness. To assure double blinding, four enumerators conducted the affective tests and the experiment without information (neither the enumerator nor the participants knew the content of the products), while the two other enumerators conducted the experiment with information about the content of the products. The enumerators were trained for one day on the experiment as well as on the use of electronic tablets for collecting the data.

Next, participants were asked some demographic and socioeconomic questions to assess their gender, age, education, wealth, and income. The questionnaire was programmed with the software CSPro (United States Census Bureau, 2016) onto electronic tablets (Kindle Fire 7, Amazon Inc., Seattle, WA, USA). These tablets were subsequently used by the trained enumerators to enter the data, which were then uploaded to a central server immediately after they were collected.

\subsection{Affective tests}

Next, consumers were asked to evaluate the products through affective tests. Each participant was provided with about $50 \mathrm{~g}$ of each product, cooked in the standard manner and presented in small cups, all in the same fashion and at the same temperature. Consumers were asked to taste and evaluate each product in a given order, which was randomized to avoid first sample and order bias. They were asked to provide a hedonic score on a 5-point Likert scale (dislike very much, dislike, neither like nor dislike, like, like very much) for different sensory characteristics (appearance, aroma, texture in hand, flavor, texture in mouth, taste) 
and overall (not an average, but a separate overall evaluation). The products were identified with a neutral symbol, randomly assigned (A: open rectangle; B: open triangle; C: closed circle; D: open circle; E: open diamond) (Table 2, second column). The affective tests were conducted double blind: neither the enumerator nor the participants knew the content of the different products at this stage.

\subsection{Economic experiments to determine willingness-to-pay - information treatments}

After the affective tests, the products were removed and the WTP of consumers was elicited with experimental auctions. The participants were presented with the same five products, but now in dry flour format, packed in clear plastic bags with $250 \mathrm{~g}$ of flour in each, with a plain white rectangular label inserted in the bag, labelled with a symbol or symbol plus text printed in black ink, depending on the information treatment (Table 2). Participants were able to link the flours in the auction to the products they tasted as they were both presented labeled with the same symbols (or symbol plus text for the information treatments) and presented in the same order.

To distinguish the WTP for the products based on their taste and sensory evaluation rather than on other characteristics such as ease of cooking (instant versus conventional), nutritional content (micronutrients), and origin of the micronutrients (commercial or natural food-to-food fortification), the participants were randomly divided into two equal groups. Participants from group 1 first conducted the experiment without any additional information about the content of the products, which were presented to them with a label bearing the same symbol as that used in the affective test. Therefore, their bids reflected the WTP for the sensory characteristics. After this first round of experiments, the same group 1 participants were given the information about the content of the products, and the experiment was repeated. Because going through the exercise twice might cause participant fatigue and bias the results, the other half of the participants, group 2, went straight from the affective tests to the auctions with information. All the information about the products was provided on the labels, together with the same symbols that were used during the affective test (Table 2, last column).

The text on the labels contained a simple description of the product translated into French. The labels were further translated into the local language, Wolof, by the enumerators, and some time was provided for the participants to ask questions. Because instant porridges are not well known in Senegal, the benefits of the instant pearl millet flours in terms of time and energy saved were explicitly explained. The benefits of the micronutrients, on the other hand, are generally well known, so there was no need to provide extra information, other than that on the label.

Table 2. The different products, their codes, their labels with symbols, and their labels with both symbols and information.

\begin{tabular}{|c|c|c|c|c|}
\hline $\begin{array}{l}\text { Product } \\
\text { code }\end{array}$ & Symbol name & Symbol & Product label & Product description \\
\hline A & Rectangle & $\square$ & Farine de mil décortiqué & Decorticated millet (conventional) \\
\hline B & Triangle & $\triangle$ & Farine de mil décortiqué instantanée & Decorticated instant millet \\
\hline $\mathrm{C}$ & Filled circle & O & Farine de mil non-décortiqué instantanée & Whole grain instant millet \\
\hline $\mathrm{D}$ & Hollow circle & 0 & $\begin{array}{l}\text { Farine de mil non-décortiqué instantanée } \\
\text { avec micronutriments }\end{array}$ & $\begin{array}{l}\text { Decorticated instant millet fortified } \\
\text { with commercial premix }\end{array}$ \\
\hline $\mathrm{E}$ & Diamond & $\diamond$ & $\begin{array}{l}\text { Farine de mil non-décortiqué instantanée } \\
\text { avec micronutriments, carottes et bouye }\end{array}$ & $\begin{array}{l}\text { Whole grain instant millet fortified } \\
\text { with both commercial premix and } \\
\text { food-to-food fortification }\end{array}$ \\
\hline
\end{tabular}




\subsection{Experimental auction}

During the experimental auction, participants' WTP for the different products was elicited using the BDM mechanism (Becker et al., 1964). This procedure mimics an auction; the participant bids against a random price, drawn from a random distribution. If the bid is higher than the random price, the participant buys the product at the random price, while if the bid is lower, there is no transaction. This mechanism is incentivecompatible, meaning that the optimal bidding strategy of the participants is to bid their true WTP (unlike, for example, first-price sealed envelope auctions). The most convenient way is to use a random uniform distribution, around the mean expected value, from 0 to twice that value, with increments equal to the lowest currency value used in the local market, which in this case were coins of 50 FCFA. These numbers were printed on pieces of paper and put in an envelope or bag.

To ensure that participants understood the procedure, it was first described in detail and subsequently illustrated with a numerical example, to demonstrate that it was in the participant's best interest to reveal his or her true WTP. Next, a test round was conducted, as this improves understanding and reduces bias (Morawetz et al., 2011); for this round, participants were asked to bid for each of two different small packets of biscuits. One of the products was then selected randomly as binding, by letting the participant draw a number (either 1 or 2) from an envelope. Next, the participant was asked to pick a random number from a set of prices (50, 100 , or 150, written on pieces of paper and put in an envelope) around the average value of the biscuits. The test round experiment was conducted with real money, and if the participant won the auction, he or she purchased the test product at the random price.

The test round was followed by the main round, in which each participant was asked to make a bid for each of the five millet products. Afterwards, one product was selected as binding, by inviting the participant to draw a number from a uniform random distribution (from 50 FCFA, in increments of 50 FCFA, up to 600 FCFA, approximately twice the value of the product, 300 FCFA). If the bid was higher than the random price, the participant purchased the product at the random price.

\subsection{Analysis of affective tests and experimental auctions}

The affective tests used a five-point Likert scale (1-dislike very much, 2-dislike, 3-neutral, 4-like, 5-like very much). Therefore the resulting variables are ordinal in nature (Stevens, 1946), and ordinal regression is the indicated model. This model is also called the 'proportional odds' model by statisticians (McCullagh, 1980) and the 'ordered logit' mode by economists (Greene, 1991; Train, 2003).

In its basic form, let respondents score two products, distinguished by a binary variable $x$, using a set of ordered categories. Let $y$ be the score and $v_{k}=P(y \leq k)$, or the probability that a score $y$ falls at or below a certain level $k$. The logarithm of the odds of $v_{k}$, also called the logit, is then modelled as a linear function of the independent variables, formally:

$$
\operatorname{Logit}\left(v_{k}\right)=\operatorname{Ln} \frac{P(y \leq k)}{1-P(y \leq k)}=\alpha_{k}+\beta^{\prime} x
$$

The coefficient $\beta$ represents the change in the log odds (the logarithm of the odds) for a unit change in the explanatory variable $x$. If $x$ is binary, $\beta$ is the change in the log odds, and its exponent $e^{\beta}$ represents the odds that one product is rated higher than the other, over the odds that the other product is rated higher, also called the odds ratio (Bellon et al., 2006). The model can be expanded to analyze the scores for different products $j$, each with a vector of attribute vector $\mathrm{x}_{j}$, by respondent $i$. The scores of different products by one respondent could be correlated, so an individual effect $u_{i}$ needs to be added (De Groote et al., 2010a), and the model becomes:

$$
\operatorname{Logit}\left(v_{i j k}\right)=\alpha_{k}+\beta^{\prime} x_{j}+u_{i}
$$


If the respondents are randomly selected, the standard procedure assumes that $u_{i}$ is randomly distributed, also called the random effects model. Such models have been used to analyze farmer participatory evaluation of new technologies (De Groote et al., 2010a) and consumer evaluation of maize products (De Groote et al., 2014). The effects of consumer characteristics $z_{i}$ can also be included in the analysis using both direct effects (vector $\gamma$ ) and cross effects (matrix A) (De Groote et al., 2011), resulting in:

$$
\operatorname{Logit}\left(v_{i j k}\right)=\alpha_{k}+\beta^{\prime} x_{j}+\gamma^{\prime} z_{i}+x_{j}^{\prime} A z_{i}+u_{i}
$$

This model was estimated with the ordered logit regression (xtologit with random effects) using the Stata software, version 15 (StataCorp LLC, College Station, TX, USA).

The contribution of the each of the individual sensory characteristics to the overall evaluation was analyzed using linear regressing of the overall score on the scores of the individual sensory characteristics. When the sum of the coefficients of this regression add up to about 1, as is often the case (for example 0.99 in a study in Eldoret, Kenya (De Groote et al., 2020)), they can be interpreted the weights of the individual sensory characteristics in the overall evaluation (De Groote et al., 2020).

To evaluate whether consumers were willing to pay a premium for the products' traits, pairwise tests were first conducted, comparing the improved products (from B to E) to the basic product (A), and that for the three sets of bids: group $1 \mathrm{a}$ - without information; group $1 \mathrm{~b}$ - the same participants as $1 \mathrm{a}$ but now with information; and group 2 - with information.

For the analysis of WTP, the dependent variable is $W T P_{i j}$ or consumer $i$ 's willingness-to-pay for product $j$, a quantitative variable on a ratio scale, and can be analyzed using a linear model. The WTP for the different traits can be included as binary variables in a random effects model:

$$
W T P_{i j}=\alpha+\beta x_{j}+u_{i}+v_{i j}
$$

Because the main interest here was the WTP for specific traits, in this model $x$ represents a vector of traits, not products like in the ordinal regression. The attribute vector consisted of the following binary variables: instant (vs conventional), whole grain (yes/no) fortified with commercial premix (yes/no), fortified with natural ingredients (yes/no). Finally, the effect of consumer characteristics was analyzed by adding a vector $\mathrm{z}$ with age, gender, income and education level, and a cross effects matrix A to the model:

$$
W T P_{i j}=\alpha+\beta^{\prime} x_{j}+\gamma^{\prime} z_{i}+x_{j}^{\prime} A z_{i}+u_{i}+v_{i j}
$$

The WTP models were estimated with the generalized least squares (GLS) module xtreg in Stata version 15.

\subsection{Cost analysis}

To compare participants' WTP to the retail cost of the products, these costs were estimated for the different flour products. They included the purchase cost of the ingredients (sifted and whole millet flour, commercial premix, and powdered carrot and baobab for food-to-food fortification), and also the processing costs for extrusion and drying (depreciation cost for the equipment, energy and labor costs). We also estimated the marketing costs such as packaging and marketing, and added an estimated profit markup for the operator. Finally, we compared the expected retail cost to the consumer's willingness-to-pay obtained in the experiment, in order to compare how competitive the new products would be in the market. The cost of millet grain at the time of the survey was FCFA 250/kg (ANSD, 2018) 


\section{Results}

\subsection{Consumer characteristics}

Both men and women participated, but women were in the majority (69\%). Most participants were literate $(81 \%)$, with an average of seven years formal education and an average age of 35 years. Their main economic activities were business, and salaried and casual labor, with agriculture accounting for only $1 \%$. These results confirm that the participants were young and predominantly urban. The average household monthly expenditure on food was 122,000 FCFA (US\$1 = FCFA 600 at the time of the study), and there were no significant differences in monthly income between men and women (Table 3).

\subsection{Affective tests}

\section{- Analysis of consumer evaluation in affective tests using mean scores}

After the socioeconomic questions, participants were asked to taste and evaluate the five (cooked) products under study, on a five-point scale, for the standard five attributes and overall. The results show that consumers could distinguish between the different products: on all the attributes they scored the traditional porridge (A) higher than the new products (Figure 3). Overall, product A, porridge from conventional sifted millet flour, received the highest scores (average of 3.8), followed closely by product B, instant porridge from sifted flour (3.7). The next products, in order of appreciation, were product $\mathrm{E}$, instant whole millet fortified with micronutrients from both industrial and natural sources and Product $\mathrm{C}$, instant porridge from whole flour, and they scored substantially lower (3.5) than the base product. The product with the lowest scores was product $\mathrm{D}$, instant porridge from sifted flour fortified with premix. The results clearly indicate that the participants preferred the classic, sifted flour porridge, and showed slightly less appreciation for instant porridge; there was some dislike for whole meal porridge and, especially, for industrial premix.

Table 3. Descriptive statistics of the participants, Dakar, Senegal $(n=296)$.

\begin{tabular}{|c|c|c|c|c|}
\hline Category & Characteristics & Mean or \% & St. $\operatorname{dev}^{2}$ & $\mathbf{n}$ \\
\hline \multirow[t]{4}{*}{ Demographics } & Household size & 8.3 & 6.5 & 296 \\
\hline & Age & 34.6 & 12.4 & 296 \\
\hline & Completed years of education & 6.9 & 5.1 & 296 \\
\hline & Attended madrasa (\%) & 61 & & 182 \\
\hline \multirow[t]{2}{*}{ Income food expenditure } & Monthly food expenditure (FCFA/month) 1 & 121,943 & 96,381 & 296 \\
\hline & Literate respondents $(\%)$ & 81 & & 239 \\
\hline Gender & Female $(\%)$ & 69 & & 204 \\
\hline \multirow[t]{4}{*}{ Marital status } & Single & 40 & & 119 \\
\hline & Married & 47 & & 140 \\
\hline & Divorced & 8 & & 24 \\
\hline & Widow(er) & 4 & & 13 \\
\hline \multirow[t]{4}{*}{ Purchasing of cereal food items by } & Wife & 46 & & 138 \\
\hline & Other family member & 25 & & 75 \\
\hline & Together & 23 & & 67 \\
\hline & Husband & 6 & & 16 \\
\hline \multirow[t]{5}{*}{ Occupation } & Business (nonagricultural) & 64 & & 190 \\
\hline & Student & 18 & & 52 \\
\hline & Salaried employment & 14 & & 40 \\
\hline & Casual labor & 4 & & 12 \\
\hline & Agriculture & 1 & & 2 \\
\hline
\end{tabular}

${ }^{1} 1 \mathrm{US} \$=600 \mathrm{FCFA} ;{ }^{2}$ st. dev. $=$ standard deviation. 


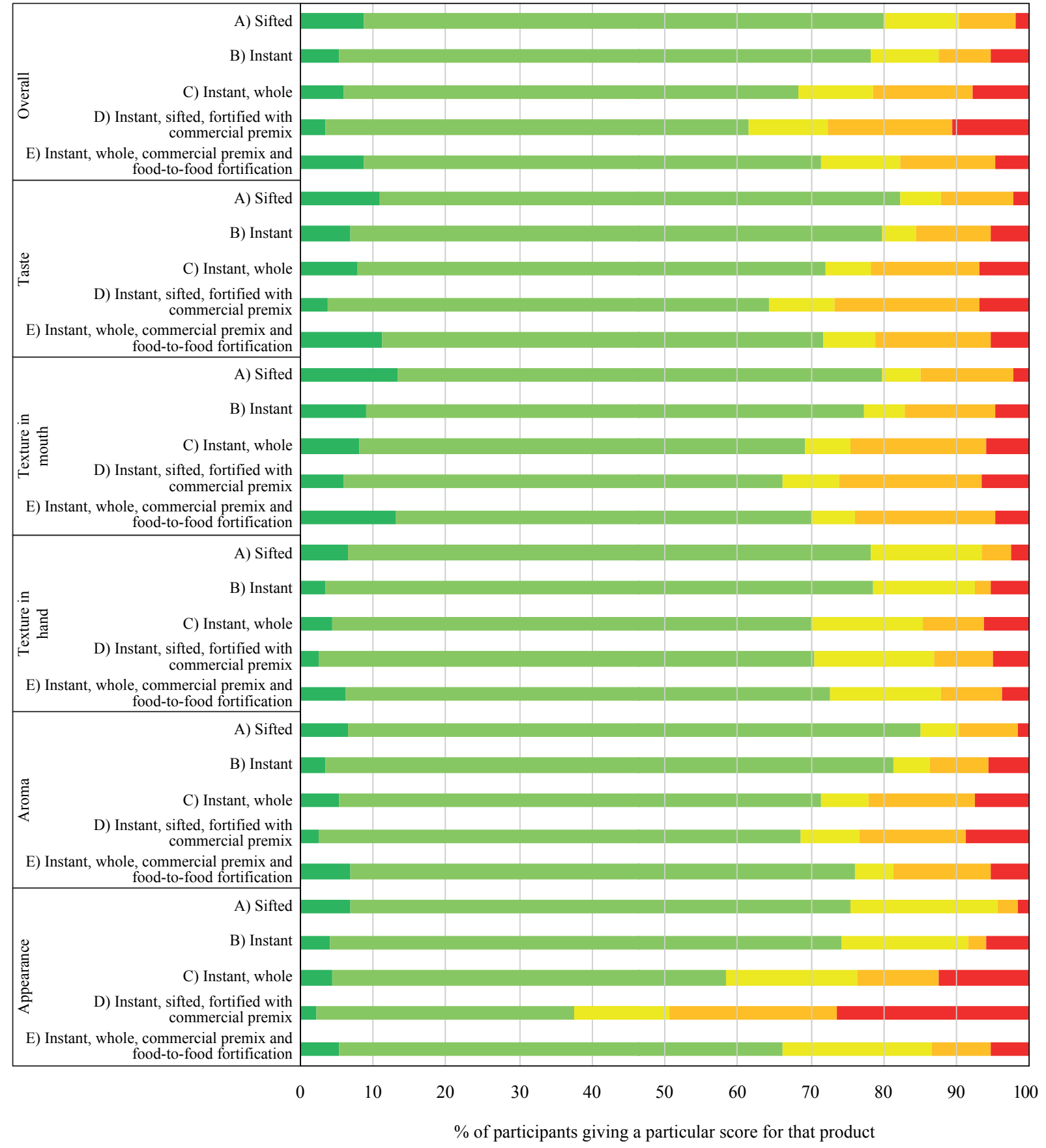

Like very much Like Neither like or not like Do not like Do not like at all

Figure 3. Consumer affective tests for the five products, scored on a five-point Likert scale, for attributes - appearance, aroma, texture and taste, and for overall appreciation.

The scores for the individual attributes of appearance, aroma, taste, texture in hand, and texture in the mouth (all for the cooked products) followed very similar patterns as those for the overall scores (Figure 3), although the scores for some traits, e.g. texture in hand, showed less differences between the products, and the scores for others, e.g. appearance, more. The differences in scores for appearance particularly were more pronounced, with products $\mathrm{C}$ and, especially, $\mathrm{D}$ receiving much lower scores, indicating that consumers did not appreciate the appearance of whole grain flour and that of flour with added industrial premix. 


\section{- Analysis of consumer evaluation of the new products in affective tests using ordinal regression}

As the evaluation scores are ordered categorical data, ordinal regression (Equation 2) was used for the statistical analysis (Figure 4). The regression results for the overall score showed a similar pattern to that of the mean scores described above, but the regression analysis allows us to distinguish the significant effects. Conventional sifted millet flour received significantly higher scores than all the new products, as shown by their negative coefficients (or log odds ratios).

The results of the analysis followed the same general trend for all the sensory attributes, indicating that the scores for the different attributes are highly correlated, although the magnitude of the differences varies. Product B, instant porridge from sifted flour, scored second best on all traits. However, none of the differences were significant, including for overall evaluation, as indicated by the error bars in Figure 4. This indicates either that instant porridge was not distinguished from the conventional products, or that the consumers were not concerned about the differences between them. In either case, the product should be acceptable to consumers in the target population, the low- and medium income urban consumers. Product $\mathrm{C}$, instant porridge from whole grain flour, was the next product in terms of evaluation, but the differences with product A were small, although significant for all traits, including overall, except for texture in hand and taste. So whole meal is not as well liked as sifted meal, but the difference is small. Product $\mathrm{D}$, instant porridge with premix, clearly scored lowest, with large negative and significant coefficients for all the attributes. Clearly, this type of premix is not liked, at least not at the levels used in this product, which were determined to reach the objective of $25 \%$ of RDA for iron and vitamin A. The product received particularly low scores for appearance, likely because the added iron in the fortification premix gave the porridge a dark appearance, and it also scored low for aroma and taste. Finally, product E (instant porridge from whole flour fortified with premix and natural ingredients), scored slightly below product $\mathrm{C}$ (whole flour but not fortified), for all attributes. This indicates that replacing the premix partly with food-to-food fortification improves the sensory characteristics of the porridge substantially.

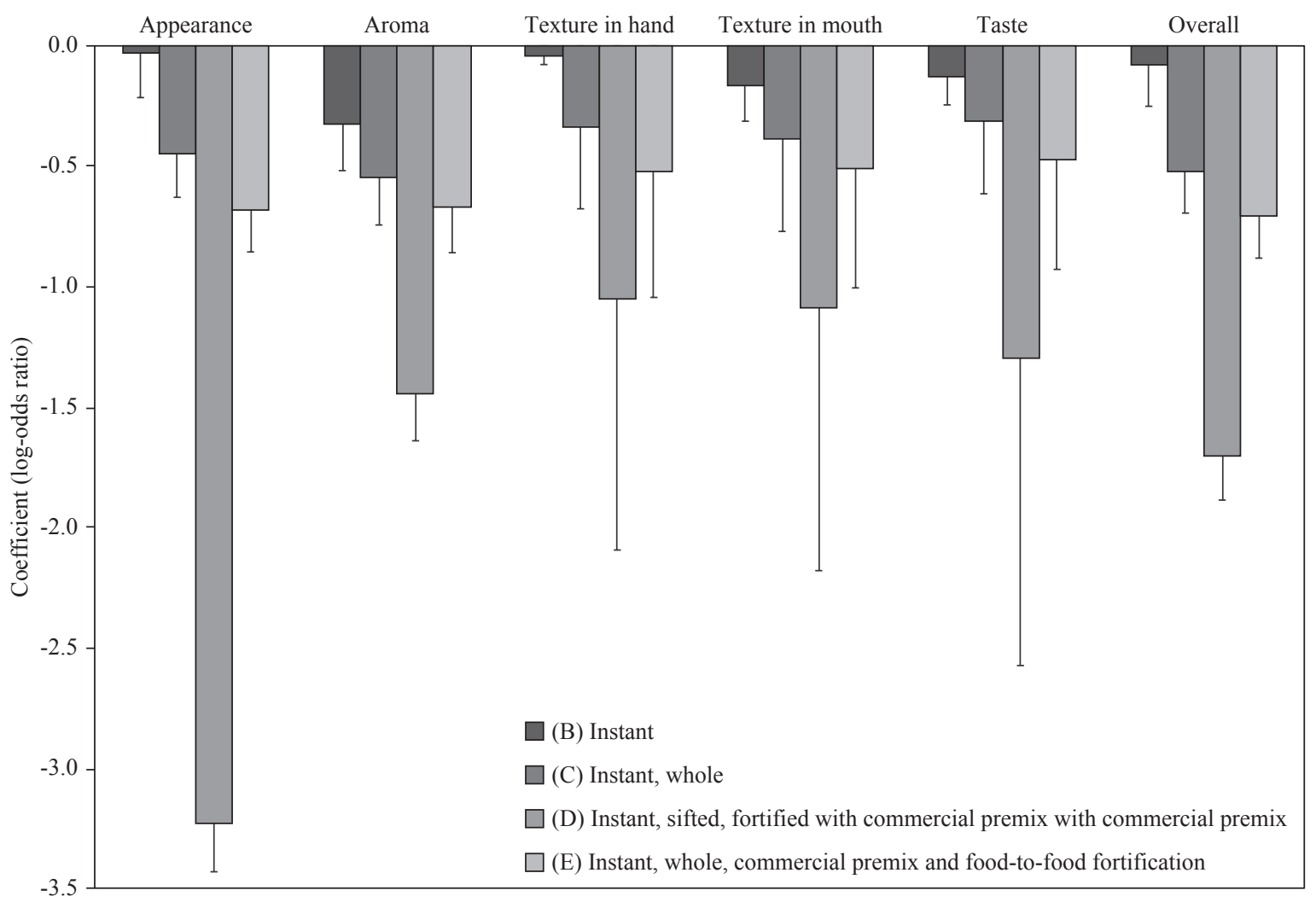

Figure 4. Results of the affective tests for four new products relative to the conventional sifted flour. 
We further evaluated how the product traits (whole meal, instant, fortified with commercial premix and food-to-food fortified) performed on the different sensory attributes. Therefore, the scores for overall evaluation, and those for evaluation of the different sensory attributes were regressed against the product traits, expressed as binary variables, with zero for the base product A, porridge from sifted flour (Table 4). Generally, the scores of the product traits for the different sensory attributes followed the same tendency as the scores for the overall evaluation. As indicated by the size of the regression coefficient, the trait food-tofood fortification was the most appreciated, while participants were indifferent to the instant trait but did not like the whole meal trait, nor the fortification with premix.

Only food-to-food fortification scored higher than the base product, as indicated by the positive and significant coefficients for all attributes as well as overall (coefficient 1.4). The scores for instant porridges, on the other hand, were not significantly different from zero, either for the specific attributes or the overall evaluation, indicating that consumers did not distinguish between instant and conventional porridge or else were indifferent to the differences between them. Also, whole meal porridge was less well liked than porridge made from decorticated flour, although the differences were only significant for overall appreciation and appearance (both -0.4). Appearance, with a large negative coefficient (-0.4) therefore seems to be the major factor that led to the lower overall score for porridge made from whole meal flour. Finally, fortification with commercial premix had a strongly negative effect on the scores. The largest effects were found for appearance (-3.1) followed by taste $(-1.2)$, so clearly consumers can distinguish products fortified with commercial premix, and they do not like the effect it has on the different attributes, especially appearance and taste.

\section{- Factors affecting overall evaluation of different millet products}

Using ordinary least squares regression following Equation 4 we analyzed the contribution of the scores for individual sensory properties to the overall scores of the products (Table 5). As the coefficients are all significant, and they roughly add up to 1, they can be interpreted as the approximate weights, or the contribution that the scores for different attributes make to the overall score and therefore appreciation of the product. The results show that texture in hand is the most important sensory attribute, with a coefficient of 0.25 . The interpretation of this result is that a unit change in the score for texture in hand will increase the overall score by $25 \%$. The next attribute was texture in the mouth $(0.22)$, followed by aroma $(0.21)$ and appearance (0.13). Somewhat surprisingly, taste had the lowest weight (0.13).

Table 4. Analysis of consumer evaluation of different traits and overall. ${ }^{1}$

\begin{tabular}{|c|c|c|c|c|c|c|c|c|c|c|c|c|c|c|c|c|c|c|}
\hline \multirow[t]{2}{*}{ Traits } & \multicolumn{3}{|c|}{ Overall } & \multicolumn{3}{|c|}{ Appearance } & \multicolumn{3}{|c|}{ Texture in hand } & \multicolumn{3}{|l|}{ Aroma } & \multicolumn{3}{|c|}{ Texture in mouth } & \multicolumn{3}{|l|}{ Taste } \\
\hline & Coeff. & St. err. & Sig. & Coeff. & Std. err. & Sig. & Coeff. & Std. err. & Sig. & Coeff. & Std. err. & Sig. & Coeff. & Std. err. & Sig. & Coeff. & Std. err. & Sig. \\
\hline Whole & -0.44 & 0.18 & $* *$ & -0.42 & 0.18 & $* *$ & -0.29 & 0.19 & & -0.23 & 0.19 & & -0.23 & 0.17 & & -0.18 & 0.18 & \\
\hline Instant & -0.07 & 0.18 & & -0.03 & 0.18 & & -0.04 & 0.20 & & -0.32 & 0.20 & & -0.16 & 0.17 & & -0.13 & 0.18 & \\
\hline $\begin{array}{l}\text { Fortification } \\
\text { with premix }\end{array}$ & -1.63 & 0.18 & $* * *$ & -3.19 & 0.20 & $* * *$ & -1.00 & 0.19 & $* * *$ & -1.13 & 0.19 & $* * *$ & -0.93 & 0.17 & $* * *$ & -1.16 & 0.17 & $* * *$ \\
\hline $\begin{array}{l}\text { Food-to-food } \\
\text { fortification }\end{array}$ & 1.45 & 0.25 & $* * *$ & 2.97 & 0.26 & $* * *$ & 0.82 & 0.27 & $* * *$ & 1.01 & 0.26 & $* * *$ & 0.82 & 0.24 & $* * *$ & 1.01 & 0.25 & $* * *$ \\
\hline Constant & 2.02 & 0.15 & $* * *$ & 3.27 & 0.20 & $* * *$ & 3.54 & 0.21 & $* * *$ & 2.88 & 0.19 & $* * *$ & 2.15 & 0.15 & $* * *$ & 2.41 & 0.16 & $* * *$ \\
\hline Sigma & 0.93 & 0.18 & $* * *$ & 1.71 & 0.26 & $* * *$ & 2.12 & 0.32 & $* * *$ & 1.01 & 0.20 & $* * *$ & 0.83 & 0.16 & $* * *$ & 0.89 & 0.17 & $* * *$ \\
\hline Observations & 1,480 & & & 1,480 & & & 1,480 & & & 1,480 & & & 1,480 & & & 1,480 & & \\
\hline $\begin{array}{l}\text { Number of } \\
\text { participants }\end{array}$ & 296 & & & 296 & & & 296 & & & 296 & & & 296 & & & 296 & & \\
\hline
\end{tabular}

${ }^{1}$ Coeff. $=$ coefficients; Sig. $=$ significance; Std. err $=$ standard error. Significance level $* * * P<0.01, * * P<0.05, * P<0.1$. 
Table 5. Factors affecting overall evaluation for instant millet products.

\begin{tabular}{llll}
\hline Overall score & Coefficients & Standard error & Significance \\
\hline Constant & 0.42 & 0.032 & \\
Appearance & 0.13 & 0.009 & $* * *$ \\
Aroma & 0.21 & 0.014 & $* * *$ \\
Texture in hand & 0.25 & 0.014 & $* * *$ \\
Texture in mouth & 0.22 & 0.017 & $* * *$ \\
Taste & 0.13 & 0.019 & $* * *$ \\
$\mathrm{R}^{2}$ adjusted & 0.89 & & \\
Standard error & 0.28 & & \\
N observations & 1,480 & & \\
N participants & 296 & & \\
\hline
\end{tabular}

\subsection{Experimental auctions and willingness to pay}

\section{- Statistical analysis with pairwise t-tests}

After the affective test, participants were asked to state their WTP for the five millet flours, now packed in clear plastic bags of $250 \mathrm{~g}$, with the BDM mechanism, and either with or without information about the content of the flours (Figure 5). To evaluate whether consumers were willing to pay a premium for the products' traits, pairwise tests were first conducted, comparing the improved products (from B to E) to the basic product (A), and that for the three sets of bids: group 1a - without information ( $\mathrm{n}=147$, randomly assigned); group $1 \mathrm{~b}$ - the same 147 participants as 1a but now with information; and group 2 - with information $(\mathrm{n}=149)$ (Table 6). For ease of interpretation, the premiums were also calculated as a percentage over the WTP for product A. The differences in WTP for new products compared to the base product were statistically analyzed using pairwise $t$-tests (Table 6; the significant differences of those tests are also indicated in Figure 5). Even though participants were able to differentiate between products in the affective tests (Figure 3), there were no significant differences in WTP for the five products if no additional information was provided (Figure 5: group 1a-without information). The WTP for this group was based solely on the affective tests that the participants had just concluded in the previous step.

After the first BDM exercise without information, the same group 1 participants were given information about the content of the products and offered a second chance to make bids on the five flours, now with both the symbol and the content information. In this second round, they were willing to pay significant premiums for products $\mathrm{B}$, instant $(9 \%), \mathrm{D}$, fortified with premix (17\%) and $\mathrm{E}$, fortified with premix and powdered carrot and baobab (food-to-food fortfification) (28\%) (Figure 5: group 1b - after information). The effect for whole grain flour on WTP was not significant.

The participants in group 2 went straight from the affective tests to the WTP exercise with information (Figure 5: group 2 - with information). Consumers in this group were willing to pay a significant premium for product E, with premix and food-to-food fortification (26\%), but were only willing to accept product C, with whole flour, at a (significant) discount of $10 \%$. In this group, however, there was no premium for instant products. This indicates that consumers, when given the relevant nutritional information, are willing to pay a premium for products with both premix and food-to-food fortification (Table 6). For both groups with information, the WTP for the conventional product decreased compared to the WTP of the group without information for this product (16 and 19\% respectively). 


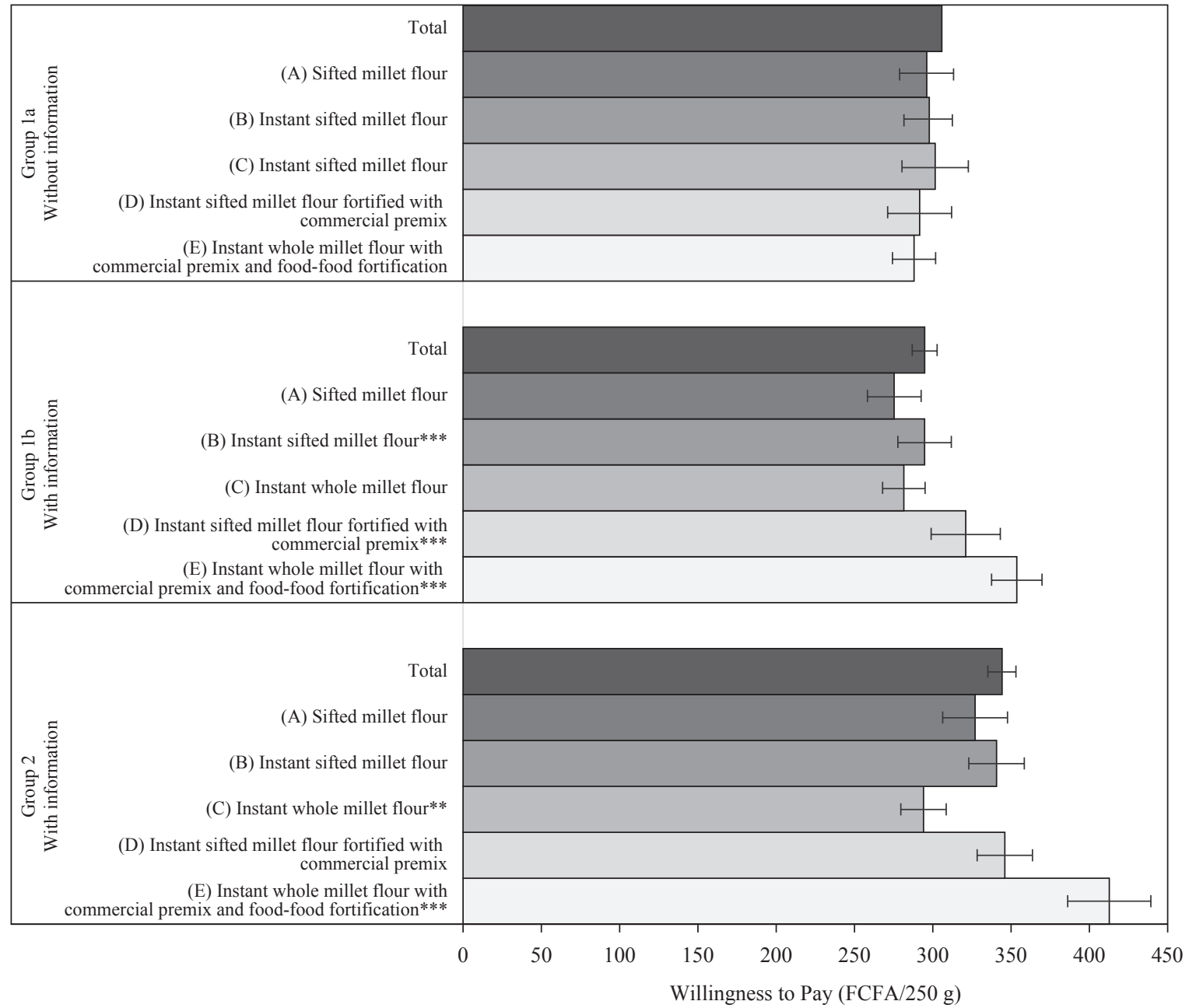

Figure 5. Mean willingness-to-pay for different millet products, with and without information (in FCFA/250 g of the milled cereal mix). $* * * P<0.01, * * P<0.05, * P<0.1$.

\section{- Willingness-to-pay for traits - regression analysis with short model}

Since the main interest of this study was to understand WTP for specific product traits, we regressed WTP for the products on their traits: instant, whole meal, fortification with commercial premix, and food-to-food fortification. First, we present the results separately for the three information treatments groups (Figure 6).

When no information on the products was provided (group 1a), none of the traits affected WTP, indicating that consumers do not change their WTP in function of the sensory evaluation, even if the latter showed some differences. Even with information, however, and in both group $1 \mathrm{~b}$ and group 2, instant or fortification with commercial premix only received small and not significant premiums. However, with information some effects emerge. The effect was smaller for group $1 \mathrm{~b}$, who offered to pay a premium of 46 FCFA for foodto-food fortification (but no significant effect on other traits was observed) while participants from group 2 were willing to pay a premium of 112 FCFA for the same trait. Similarly, without information there was no difference in WTP for whole grain flours, but consumers in group 2 (directly with information) were only willing to buy whole flour products at a discount of 45 FCFA. The negative effect on WTP indicates a negative attitude towards products made with whole flours. This underscores the important role played by the availability of information about product traits in consumers' decision-making processes and WTP. 
Table 6. Pairwise comparison of willingness-to-pay for improved products (B to E) with the standard (A). ${ }^{1}$

$\begin{array}{lrllll}\text { Product } & \text { Mean } \begin{array}{l}\text { Premium / } \\ \text { discount (\%) }\end{array} & \begin{array}{l}\text { Mean } \\ \text { diff. }\end{array} & \begin{array}{l}\text { Std. } \\ \text { dev. }\end{array} & \text { N } & P<z \\ \end{array}$

\begin{tabular}{|c|c|c|c|c|c|c|c|}
\hline Group 1a & (A) Decorticated millet (conventional) & 296 & & & & 146 & \\
\hline \multirow{4}{*}{$\begin{array}{l}\text { - before } \\
\text { information }\end{array}$} & (B) Decorticated instant millet & 297 & 0 & 0.69 & 109.02 & 146 & \\
\hline & (C) Whole grain instant millet & 301 & 3 & 9.51 & 199.13 & 142 & \\
\hline & (D) Decorticated instant millet fortified with premix & 291 & -1 & $(4.42)$ & 142.32 & 147 & \\
\hline & $\begin{array}{l}\text { (E) Whole grain instant millet fortified with premix } \\
\text { and food-to-food fortification }\end{array}$ & 288 & -2 & $(4.48)$ & 125.78 & 145 & \\
\hline \multirow{5}{*}{$\begin{array}{l}\text { Group 1b } \\
\text { - after } \\
\text { information }\end{array}$} & (A) Decorticated millet (conventional) & 272 & & & & 142 & \\
\hline & (B) Decorticated instant millet & 296 & 9 & 24.47 & 111.86 & 142 & $* * *$ \\
\hline & (C) Whole grain instant millet & 283 & 3 & 7.98 & 172.72 & 141 & \\
\hline & (D) Decorticated instant millet fortified with premix & 323 & 17 & 47.20 & 204.27 & 143 & $* * *$ \\
\hline & $\begin{array}{l}\text { (E) Whole grain instant millet fortified with premix } \\
\text { and food-to-food fortification }\end{array}$ & 356 & 30 & 80.28 & 196.49 & 142 & $* * *$ \\
\hline \multirow{5}{*}{$\begin{array}{l}\text { Group } 2 \\
\text { - with } \\
\text { information }\end{array}$} & (A) Decorticated millet (conventional) & 328 & & & & 147 & \\
\hline & (B) Decorticated instant millet & 341 & 4 & 13.10 & 147.27 & 147 & \\
\hline & (C) Whole grain instant millet & 294 & -10 & $(32.26)$ & 158.50 & 148 & $* *$ \\
\hline & (D) Decorticated instant millet fortified with premix & 346 & 6 & 19.93 & 184.93 & 148 & \\
\hline & $\begin{array}{l}\text { (E) Whole grain instant millet fortified with premix } \\
\text { and food-to-food fortification }\end{array}$ & 414 & 27 & 86.99 & 230.30 & 148 & $* * *$ \\
\hline
\end{tabular}

For further statistical analysis, we pooled the data and estimated a random effects, generalized least squares (GLS) model with the cross effects of traits and information treatments following Equation 5 (Table 7). The main effects were not significant, confirming that for the category of consumers without information, there were no significant premiums or discounts for any of the traits. Among the consumers of group $1 \mathrm{~b}$, after receiving information, the cross effects of food-to-food fortification were high and significant, as this group was willing to pay a premium of 56 FCFA. This premium was even higher for group 2, at 131 FCFA. Further, in group 2, the WTP for whole meal flour was also significant and negative, indicating that consumers in this group were only willing to buy whole meal flours at a discount of 53 FCFA. We also note that consumers were not willing to pay a premium for instant flours, either before or after being provided with information.

\section{- Willingness-to-pay-regression, long model}

To analyze which factors, other than the traits, affected WTP, we used a random effects model (long model) that included the product traits and the socioeconomic characteristics of the participants (gender, age, level of education, and income) and their cross effects (Equation 4) (Table 8). However, we do not interpret the main effects of the traits as they represent a shift in the constant at zero value for all socioeconomic characteristics.

The gender (group 1b) and age (groups 1a and 1b) of participants had a significant effect on the WTP for traits, while education and income did not. The cross-effects of gender and income did not affect the WTP for traits either jointly or individually and were therefore dropped from the analysis. Age had a mainly negative effect, indicating that WTP decreased with age, and this was significant for the first two groups. The age cross-effects were only significant for consumers without information; for participants in this group, WTP for instant products and products fortified with premix traits reduced by 2 FCFA for each year of age. 


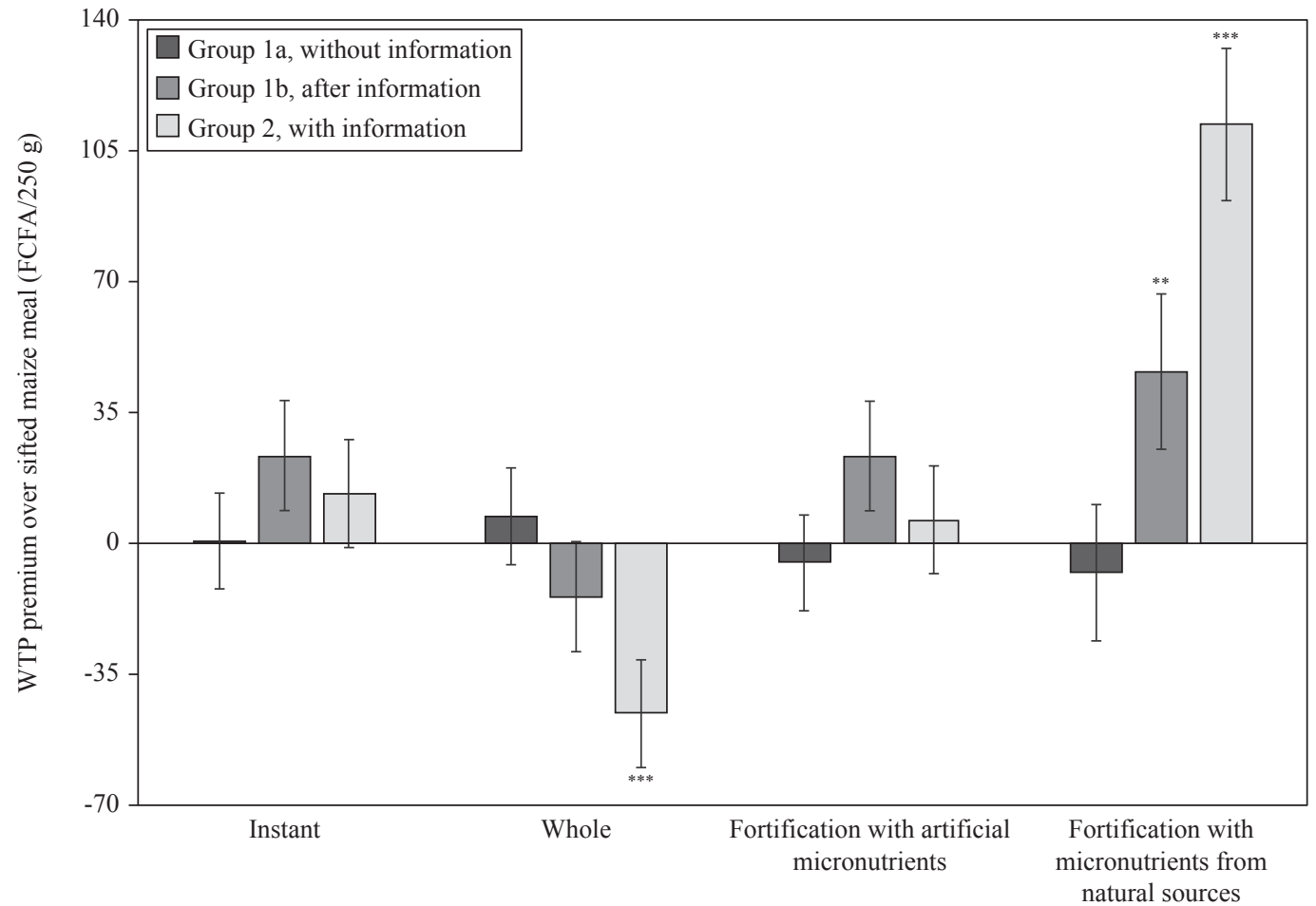

Figure 6. Willingness-to-pay (WTP) short model. *** $P<0.01,{ }^{* *} P<0.05, * P<0.1$.

Table 7. Willingness-to-pay for product traits, short random effects generalized least squares model with cross effects. ${ }^{1}$

\begin{tabular}{lllll}
\hline Groups & Variables & Coefficient & Std. dev. & \\
\hline Main effects & Constant & 295.6 & 18.76 & $* * *$ \\
& Whole & 7.890 & 14.51 & \\
& Instant & 0.855 & 14.37 & \\
& Fortification with premix & -5.277 & 14.37 & \\
& Food to food fortification & -9.829 & 20.44 & \\
& After information (group 1b) & -22.63 & 14.43 & \\
& With information (group 2) & 30.11 & 26.46 & \\
\hline Cross effects (group 1b, & Whole & -23.02 & 20.5 & \\
after info) & Instant & 23.73 & 20.4 & $*$ \\
& Fortification with premix & 27.69 & 20.37 & $* * *$ \\
\hline Cross effects (group 2, & Food to food fortification & 56.42 & 28.91 & $*$ \\
with info) & Whole & -53.36 & 20.36 & $* *$ \\
& Instant & 12.54 & 20.28 & \\
\hline Model & Fortification with commercial premix & 11.66 & 20.26 & \\
& Food to food fortification & 121.9 & 28.72 & \\
& Number of observations & 2,194 & 296 & \\
& Number of groups & 296 & 0.0577 & \\
& $\mathrm{R}^{2}$ overall & 0.0245 & 119.12 & \\
& Wald chi ${ }^{2}(14)$ & 119.12 & 0 & \\
& Prob $>$ chi & & & \\
\hline
\end{tabular}

$1 * * * P<0.01, * * P<0.05, * P<0.1$. Std. dev. = standard deviation. 
Table 8. Willingness-to-pay for product traits, random effects GLS model with cross effects. ${ }^{1}$

\begin{tabular}{|c|c|c|c|c|c|c|c|c|c|c|}
\hline \multirow[b]{2}{*}{ Category } & \multirow[b]{2}{*}{ Variables } & \multicolumn{3}{|c|}{ Group 1a (no information) } & \multicolumn{3}{|c|}{ Group 1b (after information) } & \multicolumn{3}{|c|}{ Group 2 (with information) } \\
\hline & & Coeff. & Std. err. & & Coeff. & Std. err. & & Coeff. & Std. err. & \\
\hline & Constant & 419.50 & 68.78 & ${ }^{* * * *}$ & 437.20 & 69.57 & $* * * *$ & 381.3 & 76.55 & *** \\
\hline \multirow[t]{4}{*}{ Traits } & Whole flour & 158.50 & 52.36 & ${ }^{* * *}$ & 7.679 & 59.39 & & -43.61 & 55.33 & \\
\hline & Instant flour & -48.54 & 52.10 & & -24.95 & 59.85 & & 14.92 & 55.42 & \\
\hline & Fortification with premix & 153.20 & 52.10 & ${ }^{* * *}$ & 130.00 & 59.30 & ** & -11.24 & 55.33 & \\
\hline & Food to food fortification & -267.70 & 73.60 & ${ }^{* * *}$ & -96.41 & 84.65 & & 182.3 & 78.23 & ${ }^{* *}$ \\
\hline \multirow[t]{4}{*}{ Characteristics (main effects) } & Sex & -55.99 & 37.21 & & -69.51 & 37.41 & $*$ & 58.08 & 43.41 & \\
\hline & Age & -3.85 & 1.36 & ${ }^{* * *}$ & -3.69 & 1.38 & *** & -2.231 & 1.775 & \\
\hline & Years of education & 1.319 & 3.40 & & -3.507 & 3.43 & & -0.236 & 4.234 & \\
\hline & $\begin{array}{l}\text { Monthly household food } \\
\text { expenditure (1000 FCFA) }\end{array}$ & 0.18 & 0.17 & & 0.13 & 0.18 & & 0.0137 & 0.219 & \\
\hline \multirow[t]{4}{*}{ Age cross effects } & Whole flour & 0.619 & 1.03 & & 0.434 & 1.19 & & -0.411 & 1.287 & \\
\hline & Instant flour & -2.46 & 1.03 & $* *$ & -0.379 & 1.18 & & 0.647 & 1.284 & \\
\hline & Fortified with premix & -2.24 & 1.03 & $* *$ & -1.912 & 1.17 & & 0.771 & 1.284 & \\
\hline & Food to food fortification & 4.45 & 1.45 & *** & 2.636 & 1.67 & & -2.394 & 1.814 & \\
\hline \multirow{9}{*}{$\begin{array}{l}\text { Years of education } \\
\text { cross effects }\end{array}$} & Whole flour & 1.353 & 2.57 & & 4.694 & 2.98 & & 1.570 & 3.079 & \\
\hline & Instant flour & -6.63 & 2.60 & $* *$ & -0.967 & 2.97 & & -0.188 & 3.063 & \\
\hline & Fortified with premix & -6.25 & 2.57 & $* *$ & -3.899 & 2.98 & & 0.753 & 3.063 & \\
\hline & Food to food fortification & 12.04 & 3.65 & ${ }^{* * *}$ & 7.27 & 4.20 & * & 1.528 & 4.324 & \\
\hline & Number of observations & & 727 & & & 724 & & & 743 & \\
\hline & Number of groups & & 147 & & & 147 & & & 149 & \\
\hline & $\mathrm{R}^{2}$ overall & & 0.079 & & & 0.068 & & & 0.034 & \\
\hline & Wald $\mathrm{chi}^{2}(14)$ & & 36.4 & & & 56.3 & & & 88.7 & \\
\hline & Prob $>\mathrm{chi}^{2}$ & & 0.014 & & & 0.000 & & & 0.000 & \\
\hline
\end{tabular}

${ }^{1}$ Coeff. $=$ coefficients; Std. err $=$ standard error. $* * * P<0.01, * * P<0.05, * P<0.1$.

Education significantly increased WTP for food-to-food fortification, and with each additional year of education, consumers offered a premium of 12 FCFA (without information) and 7 FCFA (after information) for this trait. On the other hand, education reduced WTP for instant products and products fortified with commercial premix among consumers without information.

\subsection{Comparing consumers' willingness-to-pay to the cost of the products}

\section{- Comparing the consumers' willingness-to-pay with the expected retail price of the products}

To determine the expected retail price of the products, we computed the cost of producing a kilogram of each, including the cost of the ingredients, the extrusion (energy, labor and extruder use), packaging and marketing, as well as a markup to cover operator profits (Table 9). The main ingredient for all the products is millet, $350 \mathrm{FCFA} / \mathrm{kg}$ for the sifted meal (products A, B and D) and $300 \mathrm{FCFA} / \mathrm{kg}$ for the whole meal (products $\mathrm{C}$ and $\mathrm{E}$ ). The quantities of commercial premix used are small, and so is their cost: $14 \mathrm{FCFA} / \mathrm{kg}$ for product $\mathrm{D}$ and $6 \mathrm{FCFA} / \mathrm{kg}$ for product $\mathrm{E}$. The costs of the ingredients of the first four products are all similar, with some discount for the whole meal of product $\mathrm{C}$. The food-to-food fortificants for product $\mathrm{E}$, dried carrot and dried baobab, on the other hand, are quite expensive, 400 and 1,061 FCFA/kg respectively, and they drive up the cost of the ingredients substantially, to 1,706 FCFA $/ \mathrm{kg}$.

Base product A does not have any processing costs other than milling, which is already included in its purchase price, while the other products incur costs for extrusion and drying, each subdivided into depreciation and costs of energy and labor. The purchase cost of the extruder was $\$ 18,000$, and assuming that it lasts for 10 years and works on 250 days per year, for 8 hours per day, the cost per hour is estimated at $\$ 0.9 / \mathrm{h}(540 \mathrm{FCFA})$ or, at a 
Table 9. Cost of production of conventional and instant cereal mixtures. ${ }^{1}$

\begin{tabular}{|c|c|c|c|c|c|c|c|c|c|c|c|c|c|}
\hline \multirow[b]{2}{*}{ Inputs } & \multirow[b]{2}{*}{ Description (1 kg product) } & \multirow[b]{2}{*}{ Unit } & \multicolumn{5}{|c|}{ Input needs for $1 \mathrm{~kg}$} & \multirow{2}{*}{$\begin{array}{l}\text { Unit cost } \\
\text { (FCFA) }\end{array}$} & \multicolumn{5}{|c|}{ Costs (FCFA/kg) } \\
\hline & & & $\mathbf{A}$ & B & C & D & $\mathbf{E}$ & & $\mathbf{A}$ & B & $\mathrm{C}$ & D & $\mathbf{E}$ \\
\hline \multirow[t]{6}{*}{ Raw materials } & Whole pearl millet flour & $\mathrm{kg}$ & & & 1 & & 0.799 & 300 & & & 300 & 0 & 239.7 \\
\hline & Sifted pearl millet flour & $\mathrm{kg}$ & 1 & 1 & & 0.998 & & 350 & 350 & 350 & 0 & 349.13 & 0 \\
\hline & Commercial premix & $\mathrm{kg}$ & & & & 0.003 & 0.001 & 5,750 & 0 & 0 & 0 & 14.375 & 5.75 \\
\hline & Baobab, dried flour & $\mathrm{kg}$ & & & & & 0.1 & 4,000 & 0 & 0 & 0 & 0 & 400 \\
\hline & Carrot, dried flour & $\mathrm{kg}$ & & & & & 0.1 & 10,609 & 0 & 0 & 0 & 0 & $1,060.9$ \\
\hline & Subtotal ingredients & FCFA & & & & & & & 350 & 350 & 300 & 363.5 & $1,706.4$ \\
\hline \multirow[t]{3}{*}{ Extrusion } & Electricity use $(7.5 \mathrm{kw}, 35 \mathrm{~kg} / \mathrm{h})$ & Kwh & & 0.210 & 0.210 & 0.210 & 0.210 & 110.9 & & 23.3 & 23.3 & 23.3 & 23.3 \\
\hline & $\begin{array}{l}\text { Extruder }(\$ 18,000,10 \mathrm{y}, \\
250 \mathrm{~d} / \mathrm{y}, 8 \mathrm{~h} / \mathrm{d})\end{array}$ & hour & & 0.029 & 0.029 & 0.029 & 0.029 & 544.5 & & 15.6 & 15.6 & 15.6 & 15.6 \\
\hline & Labor $(3 \mathrm{~h} / 35 \mathrm{~kg})$ & hour & & 0.086 & 0.086 & 0.086 & 0.086 & 225.0 & & 19.3 & 19.3 & 19.3 & 19.3 \\
\hline \multirow[t]{4}{*}{ Drying } & $\begin{array}{l}\text { Electricity }(5 \mathrm{kw} \text { coil, } 0.7 \mathrm{kw} \\
\text { fan, } 35 \mathrm{~kg} / 8 \mathrm{~h})\end{array}$ & Kwh & & 1.303 & 1.303 & 1.303 & 1.303 & 110.9 & & 144.5 & 144.5 & 144.5 & 144.5 \\
\hline & $\begin{array}{l}\text { Drying equipment (\$500, } 2 \mathrm{y} \text {, } \\
250 \mathrm{~d}, 8 \mathrm{~h} / \mathrm{d})\end{array}$ & hour & & 0.229 & 0.229 & 0.229 & 0.229 & 75.6 & & 17.3 & 17.3 & 17.3 & 17.3 \\
\hline & Labor $(35 \mathrm{~kg} / 8 \mathrm{~h})$ & hour & & 0.229 & 0.229 & 0.229 & 0.229 & 225 & & 51.4 & 51.4 & 51.4 & 51.4 \\
\hline & Subtotal extrusion & & & & & & & & & 271.3 & 271.3 & 271.3 & 271.3 \\
\hline \multirow[t]{3}{*}{ Packaging } & Material ( $\$ 4$ for 100 bags) & bags & & 4 & 4 & 4 & 4 & 24.2 & 24.2 & 24.2 & 24.2 & 24.2 & 24.2 \\
\hline & Labor $(35 \mathrm{~kg} / 1 \mathrm{~h})$ & hour & & 0.11 & 0.11 & 0.11 & 0.11 & 225 & 3.2 & 3.2 & 3.2 & 3.2 & 3.2 \\
\hline & Subtotal packaging & & & & & & & & 27.4 & 27.4 & 27.4 & 27.4 & 27.4 \\
\hline Total cost & & FCFA/kg & & & & & & & 377 & 649 & 599 & 662 & 2,005 \\
\hline
\end{tabular}

rate of $35 \mathrm{~kg} /$ hour, the deprecation cost per $\mathrm{kg}$ is $15.4 \mathrm{FCFA}$. The extruder uses $7.5 \mathrm{kw} / \mathrm{h} ; 110.9 \mathrm{FCFA} / \mathrm{kwh}$ for $35 \mathrm{~kg}$ results in $23.3 \mathrm{FCFA} / \mathrm{kg}$. With regard to labor, it takes about 3 hours to dry a batch of $35 \mathrm{~kg}$, so at $225 \mathrm{FCFA} / \mathrm{h}$ the cost is $19.3 \mathrm{FCFA} / \mathrm{kg}$. Similarly, the purchase cost of the drying equipment (fan and heating coil) was $\$ 500$, and assuming that it works for two years, at the same intensity as the extruder, the cost per hour is estimated at 75 FCFA; it takes 8 hours to dry $35 \mathrm{~kg}(0.23 \mathrm{~h} / \mathrm{kg})$, so the depreciation cost of the drying equipment is $17.1 \mathrm{FCFA} / \mathrm{kg}$. Drying uses $5 \mathrm{kw} / \mathrm{h}$ for the coil and $0.7 \mathrm{kw} / \mathrm{h}$ for the fan, or $1.3 \mathrm{kw} / \mathrm{kg}$, at a cost of $110.9 \mathrm{FCFA} / \mathrm{kwh}$ or $144.5 \mathrm{FCFA} / \mathrm{kg}$. Labor cost for $8 \mathrm{~h}$ and $35 \mathrm{~kg}$ is estimated at $51.4 \mathrm{FCFA} / \mathrm{kg}$. The total cost of extrusion is therefore estimated at $271 \mathrm{FCFA} / \mathrm{kg}$, with drying accounting for the larger part of this (213 FCFA $/ \mathrm{kg}$ ). With regard to packaging, the cost of the plastic bags (each holding $250 \mathrm{~g}$ ) is $\$ 4 / 100$ or $24 \mathrm{FCFA} / \mathrm{bag}$, and one worker can pack $35 \mathrm{~kg}$ in one hour, so labor is estimated at $104.3 \mathrm{FCFA} / \mathrm{kg}$. Further, we added an estimated 30\% markup for distribution costs and profit.

The total cost of production of basic product A was 377 FCFA $/ \mathrm{kg}$ (about US\$ 0.63), so the cost of the new products needed to be compared to this standard. The costs of the first three instant products $(\mathrm{B}, \mathrm{C}, \mathrm{D})$ were similar, between 600 and $660 \mathrm{FCFA} / \mathrm{kg}$ (with product $\mathrm{C}$ being somewhat cheaper because of the lower cost of whole meal flour) (US\$ 1-1.10), and showed an increase of $60-80 \%$ over the base product. Product E, however, with food-to-food fortification, was much more expensive at 2005 FCFA/kg (US\$ 3.3), or five times the cost of the base product.

Finally, we calculate the expected retail price per $250 \mathrm{~g}$, the expected package size, by calculating the production cost per $250 \mathrm{~g}$ plus a retail margin of $30 \%$. Then we compare the expected price to willingnessto-pay of the informed consumers (average over both information treatments) obtained in the experiment (Table 10). WTP for the base product was $300 \mathrm{FCFA} / 250 \mathrm{~g}$, about double the expected retail price of the product. WTP for product B (instant sifted), was 319 FCFA, 60\% higher than its expected price. In other words, the production of a basic instant product would make a good profit when selling at a price equal to 
Table 10. Costs and retail price of the different products, compared to consumers' willingness-to-pay (WTP) (FCFA/250 g).

\begin{tabular}{|c|c|c|c|c|c|c|}
\hline & & $\mathbf{A}$ & B & C & D & $\mathbf{E}$ \\
\hline Group & Item & $\begin{array}{l}\text { Decorticated millet } \\
\text { (conventional) }\end{array}$ & $\begin{array}{l}\text { Decorticated } \\
\text { millet instant }\end{array}$ & $\begin{array}{l}\text { Whole grain } \\
\text { millet instant }\end{array}$ & $\begin{array}{l}\text { Decorticated millet } \\
\text { instant fortified with } \\
\text { premix }\end{array}$ & $\begin{array}{l}\text { Whole grain millet } \\
\text { fortified with } \\
\text { artificial and natura } \\
\text { fortification }\end{array}$ \\
\hline \multirow[t]{5}{*}{ Cost } & Ingredients & 88 & 88 & 75 & 91 & 427 \\
\hline & Extrusion and drying & 0 & 68 & 68 & 68 & 68 \\
\hline & Packaging & 7 & 7 & 7 & 7 & 7 \\
\hline & Mark-up and distribution & 28 & 49 & 45 & 50 & 150 \\
\hline & Expected retail price & 123 & 211 & 195 & 215 & 652 \\
\hline WTP & WTP from experiment ${ }^{1}$ & 300 & 319 & 289 & 335 & 385 \\
\hline \multirow[t]{2}{*}{ Comparison } & Difference (WTP - expected retail) & 177 & 108 & 94 & 119 & -267 \\
\hline & Profit margin & 144 & 51 & 48 & 55 & -41 \\
\hline
\end{tabular}

${ }^{1}$ Calculated as the average between the WTP of both information treatments.

consumers' WTP price. WTP for product C (instant whole meal) was lower than for the base product A, as consumers were not very interested in it. However, its expected price was also lower than that of the base product, so the WTP was still $49 \%$ above the expected price, allowing for a good profit margin on this product. WTP for product D (instant sifted with premix) was substantially higher than for product B, plain sifted instant, at a small increase in cost, so the profit margin for this product was the highest at $63 \%$. Among all the products, the WTP was highest for product E, with food-to-food fortification, but was still substantially less (57\%) than the (very high) expected retail price.

\section{Discussion}

The study assesses consumer acceptance of and WTP for new pearl millet products with four different traits: instant products, whole meal products, products fortified with commercial premix, and products with food-to-food fortification. Food-to-food fortification is part of a range of food-based strategies (Ruel, 2001), complementary to other current strategies, with the potential of simultaneously addressing multiple micronutrient deficiencies, with little dietary change required by consumers (Kruger et al., 2020). The foodto-food fortification products analyzed in this study fit into food-based strategies (with biofortification and dietary diversification), that encourage the utilization of local resources and are sustainable, as they promote self-reliance and create market opportunities for locally produced foods (Burchi et al., 2011). Products like those tested here are potentially interesting to small and local enterprises because, unlike conventional fortification, they do not face the challenge of homogeneous distribution of the fortificant in the target food, which requires special dosing equipment (Chadare et al., 2019; Dary and Hurrell, 2006), or importing the vitamin and mineral premix ingredients (Kruger et al., 2020). This study fits in the growing literature on consumer research to identify factors that affect consumer acceptability, and the results confirm those from other studies showing that the acceptability of food products is affected by many factors, including as manufacturing, processing, or preparation methods (Yang and Lee, 2019).

The affective tests showed that the participating consumers could distinguish the new porridges from conventional porridge through sensory evaluation, but that they systematically scored the conventional porridge higher. This could clearly be affected by familiarity bias (Park and Lessig, 1981), as has been documented in a recent review of consumer studies (Yang and Lee, 2019). The trait-by-trait analysis shows that consumers liked the food-to-food fortified porridge, which received particularly high scores for appearance, and also for taste and aroma. Consumers did not, however, appreciate whole meal flour (in particular its appearance) or the premix used in fortification (especially for appearance, aroma and taste). The results also showed no significant effect of extrusion (the instant trait) on the evaluation scores for any of the sensory attributes. 
The experimental auctions showed no differences in mean WTP for the different traits when content information was not provided, indicating that the differences in sensory evaluation did not translate into changes in WTP. However, when providing information on the content of the products, there was a clear effect of the different traits on WTP, especially on food-to-food fortified products, which received a premium of $27-30 \%$. The effect of the other traits on WTP however, in particular instant, was only significant in one of the two treatment groups that had information. In group $1 \mathrm{~b}$, which received information only after a first round of experiments, there were significant effects of premix (17\%) and instant (9\%). However, in group 2, which received information immediately after the affective tests, only the effect of whole meal was significant and negative (-10\%). Comparing the costs of production with the WTP after receiving information indicates that the production costs are lower than the WTP for instant products, whole meal products and premix, but not for food-to-food fortified products.

The results of this study were similar to those of other studies. In a previous study in Touba, Senegal, auctions also showed that without information there was no difference in WTP between different products, but when provided with information, consumers were willing to pay a modest premium for instant flour, and a large premium for added mango and carrot extract and for added micronutrients (De Groote et al., 2018a). In a similar study in Eldoret, Kenya, consumers also preferred conventional sifted maize flour for ugali (stiff porridge), but they appreciated the new products (instant and fortified) for uji (liquid porridge), especially sifted maize and sorghum flour, and instant whole maize/sorghum flour, but not food-to-food fortified flour (De Groote et al., 2020). Here also, comparing production costs to WTP showed that whole meal of maize with sorghum, and instant flours were economical, but not food-to-food fortified flour. Base-of-pyramid consumers in Kenya and Uganda were also found to be willing to pay a premium for improved porridge flour, and providing nutrition information about the content also influenced WTP for safe and nutritious porridge flour (Chege et al., 2019).

The study has some limitations; information effects were not consistent in the two information groups, so that consumers' WTP for traits such as instant, whole meal, and fortified with premix were ambiguous. We therefore need to better understand how to present the information about the added traits. An informal demonstration for the participants of how the instant product was prepared, after the affective tests and auctions, indicated that many did not properly understand the concept of 'instant', in particular, that there were substantial time and energy benefits. Similarly, we did not explain the nutritional benefits of using whole grain vs sifted. Finally, the food-to-food fortification mixture used was too expensive.

Based on our results, we can make the following recommendations. For policy makers, it is important to note the interest of consumers in nutritious food and the potential for market-driven initiatives. Relevant policies should support the emerging food industry and, given the importance of nutrition information, support the dissemination of that information through both public and private means, in particular through the development of appropriate regulations for labeling and advertisement of food products. For local entrepreneurs and SMEs, the recommendation is to study the interest of the consumers in nutritious food but also their limited WTP, and to develop new products in collaboration with local research institutes such as ITA. Management scholars, finally, should look at balancing the demand for nutritious food with their production costs to optimize these products, and test them in real market conditions.

We conclude that there is a potential market for instant, nutritionally enhanced porridge mixtures in Dakar. This market creates opportunities for small entrepreneurs to produce and market instant food-to-food fortification products based on locally purchased ingredients, and the FPL project and ITA are currently engaged with several local producers, supporting their activities in this field. Unfortunately, the two low-cost traits, industrial premix and whole-grain flour, come with clear negative sensory aspects, while those that consumers like, e.g. food-to-food fortification, or are indifferent about, e.g. instant, come with substantial costs. It is therefore important to find the right balance between costs and desired traits, to improve the delivery of information about the nutrition and convenience aspects of the improved products, while at the same time keeping the expected retail price within the reach of the poor, for whom such interventions are 
designed. Future research activities of the project will therefore include economic analysis and optimization of the products currently manufactured by local entrepreneurs and a market penetration study.

\section{Acknowledgements}

This research was made possible through support provided by the Office of Agricultural Research and Policy, Bureau for Food Security, U.S. Agency for International Development, under the terms of Cooperative Agreement No. AID-OAA-L-14-00003, through Purdue University's Food Processing Lab (FPL). We thank the FPL director, Dr. Betty Bugusu, and the other staff for their support and Elizabeth Waygood for editing the manuscript. We are grateful to the enumerators for their work, and the participants for spending their time with us.

\section{References}

Amod, R., K. Pillay, M. Siwela and U. Kolanisi. 2016. Acceptance of a complementary food based on provitamin a-biofortified maize and chicken stew. Journal of Human Ecology 55(3): 152-159. https:// doi.org/10.1080/09709274.2016.11907019

Agence Nationale de la Statistique et de la Démographie (ANSD). 2018. Bulletin Mensuel des Statistiques Economiques de Septembre 2018. ANSD, Dakar, Senegal.

Banerji, A, C. Shyamal, H. De Groote, J.V. Meenakshi, H. Joyce and E. Manfred. 2018. Eliciting willingnessto-pay through multiple experimental procedures: evidence from lab-in-the-field in rural Ghana. Canadian Journal of Agricultural Economics/Revue Canadienne d'Agroeconomie 66(2): 231-254. https://doi.org/10.1111/cjag.12147

Becker, G.M., H. De Groot and J. Marschak. 1964. Measuring utility by a single-response sequential method. Behavioral Science 9(3): 207-299.

Bellon, M.R., M. Adato, J. Becerril and D. Mindek. 2006. Poor farmers' perceived benefits from different types of maize germplasm: the case of creolization in lowland tropical Mexico. World Development 34(1): 113-129.

Birol, E. and H.E. Bouis. 2019. Leveraging biofortified crops and foods: R4D perspective. In: P. Ferranti, E.M. Berry and J.R. Anderson (eds.) Encyclopedia of food security and sustainability. Elsevier, Oxford, UK, 181-188.

Brennan, M.A., E. Derbyshire, B.K. Tiwari and C.S. Brennan. 2013. Ready-to-eat snack products: the role of extrusion technology in developing consumer acceptable and nutritious snacks. International Journal of Food Science \& Technology 48(5): 893-902. https://doi.org/10.1111/ijfs. 12055

Burchi, F., J. Fanzo and E. Frison. 2011. The role of food and nutrition system approaches in tackling hidden hunger. International Journal of Environmental Research and Public Health 8(2): 358-373.

Chadare, F.J., R. Idohou, E. Nago, M. Affonfere, J. Agossadou, T.K. Fassinou, C. Kénou, S. Honfo, P. Azokpota, A.R. Linnemann and D.J. Hounhouigan. 2019. Conventional and food-to-food fortification: an appraisal of past practices and lessons learned. Food Science \& Nutrition 7(9): 2781-2795. https:// doi.org/10.1002/fsn3.1133

Chege, C.G.K., K.W. Sibiko, R. Wanyama, M. Jager and E. Birachi. 2019. Are consumers at the base of the pyramid willing to pay for nutritious foods? Food Policy 87: 101745. https://doi.org/10.1016/j. foodpol.2019.101745

Cheikh, N. 2018. Quality and nutritional impacts of extrusion on pearl millet and nutrient dense native plant blends. PhD-thesis, Department of Food Science, Purdue University, West Lafayette, IN, USA.

Dary, O. and R. Hurrell. 2006. Guidelines on food fortification with micronutrients. World Health Organization / Food and Agricultural Organization of the United Nations, Geneva / Rome, Switzerland / Italy.

De Groote, H., S.W. Kariuki, D. Traore, J.R. Taylor, M.G. Ferruzzi and B.R. Hamaker. 2018a. Measuring consumers' interest in instant fortified pearl millet products: a field experiment in Touba, Senegal. Journal of the Science of Food and Agriculture 98(6): 2320-2331. https://doi.org/10.1002/jsfa.8722

De Groote, H. and S.C. Kimenju. 2012. Consumer preferences for maize products in urban Kenya. Food and Nutrition Bulletin 33(2): 99-110. 
De Groote, H., S. Chege Kimenju and U.B. Morawetz. 2011. Estimating consumer willingness to pay for food quality with experimental auctions: the case of yellow versus fortified maize meal in Kenya. Agricultural Economics 42(1): 1-16.

De Groote, H., V. Mugalavai, M. Ferruzzi, A. Onkware, E. Ayua, K.G. Duodu, M. Ndegwa and B.R. Hamaker. 2020. Consumer acceptance and willingness to pay for instant fortified cereal products in Eldoret, Kenya. Food and Nutrition Bulletin 41(2): 224-243. https://doi.org/10.1177/0379572119876848

De Groote, H., E. Rutto, G. Odhiambo, F. Kanampiu, Z. Khan, R. Coe and B. Vanlauwe. 2010a. Participatory evaluation of integrated pest and soil fertility management options using ordered categorical data analysis. Agricultural Systems 103: 233-244.

De Groote, H., K. Tomlins, J. Haleegoah, M. Awool and B.N. Frimpong. 2010b. Assessing rural consumers' WTP for orange, biofortified maize in Ghana with experimental auctions and a simulated radio message. Paper presented at the Conference of the African Agricultural Economics Association. September 19-23, 2010. Cape Town, South Africa.

De Groote, H., N.S. Gunaratna, J.O. Okuro, A. Wondimu, C.K. Chege and K. Tomlins. 2014. Consumer acceptance of quality protein maize (QPM) in East Africa. Journal of the Science of Food and Agriculture 94(15): 3201-3212. https://doi.org/10.1002/jsfa.6672

De Groote, H., S.W. Kariuki, D. Traore, J.R.N. Taylor, M.G. Ferruzzi and B.R. Hamaker. 2018b. Measuring consumers' interest in instant fortified pearl millet products: a field experiment in Touba, Senegal. Journal of the Science of Food and Agriculture 98(6): 2320-2331. https://doi.org/10.1002/jsfa.8722

Dong, J. 2011. Millet has many faces. Global agricultural information network. USDA, Dakar, Senegal.

FAOSTAT. 2016. FAOSTAT production database. Food and Agriculture Organisation, Rome, Italy. Available at: http://faostat.fao.org/site/339/default.aspx

Greene, W.H. 1991. Econometric analysis. Mcmillan Publishing Company, New York, NY, USA.

Gunaratna, N.S., T. Bosha, D. Belayneh, T. Fekadu and H. De Groote. 2016. Women's and children's acceptance of biofortified quality protein maize for complementary feeding in rural Ethiopia. Journal of the Science of Food and Agriculture 96(10): 3439-3445. https://doi.org/10.1002/jsfa.7526

Guy, R. 2001. Extrusion cooking: technologies and application. Woodhead Publishing Ltd., Cambridge, MA, USA.

Kruger, J., J.R.N. Taylor, M.G. Ferruzzi and H. Debelo. 2020. What is food-to-food fortification? A working definition and framework for evaluation of efficiency and implementation of best practices. Comprehensive Reviews in Food Science and Food Safety 19(6): 3618-3658.

Layrisse, M. and C. Martinez-Torres. 1977. Fe (III)-EDTA complex as iron fortification. The American Journal of Clinical Nutrition 30(7): 1166-1174.

McCullagh, P. 1980. Regression models for ordinal data. Journal of the Royal Statistical Society: Series B 42: 109-142.

Meilgaard, M., G.V. Civile and B.T. Carr. 2007. Sensory evaluation techniques, $4^{\text {th }}$ edition. CRC Press, Boca Raton, FL, USA.

Morawetz, U.B., H. De Groote and S.C. Kimenju. 2011. Improving the use of experimental auctions in Africa: theory and evidence. Journal of Agricultural and Resource Economics 36(2): 263-279.

Park, C.W. and V.P. Lessig. 1981. Familiarity and its impact on consumer decision biases and heuristics. Journal of Consumer Research 8(2): 223-230.

Reyes-Moreno, C., J. Milan-Carrillo, R. Gutierrez-Dorado, O. Paredes-Lopez, E.O. Cuevas-Rodriguez and J.A. Garzon-Tiznado. 2003. Instant flour from quality protein maize (Zea mays L). optimization of extrusion process. Lebensmittel-Wissenschaft und-Technologie 36(7): 685-695.

Ruel, M.T. 2001. Can food-based strategies help reduce vitamin A and iron deficiencies? International Food and Policy Research Institute (IFPRI), Washington, DC, USA.

Stevens, S.S. 1946. On the theory of scales of measurement. Science 103(2684): 677-680. https://doi. org/10.1126/science.103.2684.677

Taylor, J.R.N., S.C. Barrion and L.W. Rooney. 2010. Pearl millet-new developments in ancient food grain. Cereal Foods World 55(1): 16-19. 
Taylor, J.R.N. and J.M. Awika. 2017. Millets: their unique nutritional and health-promoting attributes. In: J.R.N. Taylor and J.M. Awika (eds.) Gluten-free ancient grains: cereals, pseudocereals and legumes: sustainable, nutritious and health-promoting foods for the $21^{\text {st }}$ century. Woodhead Publishing-Elsevier, Duxford, UK, pp. 297-328.

Tomlins, K., G. Ndunguru, K. Stambul, N. Joshua, T. Ngendello, E. Rwiza, R. Amour, B. Ramadhani, A. Kapande and A. Westby. 2007. Sensory evaluation and consumer acceptability of pale-fleshed and orange-fleshed sweetpotato by school children and mothers with preschool children. Journal of the Science of Food and Agriculture 87: 2436-2446.

Train, K.E. 2003. Discrete choice methods with simulation. Cambridge University Press, Cambridge, UK. Umberger, W.J. and D.M. Feuz. 2004. The usefulness of experimental auctions in deteremining consumer's willingness-to-pay for quality-differentiated products. Review of Agricultural Economics 26: 170-185.

United States Census Bureau. 2016. Census and survey processing system (CSPro). United States Census Bureau, Washington, DC, USA.

Vilakati, N., U. MacIntyre, A. Oelofse and J.R.N. Taylor. 2015. Influence of micronization (infrared treatment) on the protein and functional quality of a ready-to-eat sorghum-cowpea African porridge for young child-feeding. LWT - Food Science and Technology 63(2): 1191-1198. https://doi.org/10.1016/j. lwt.2015.04.017

Yang, J. and J. Lee. 2019. Application of sensory descriptive analysis and consumer studies to investigate traditional and authentic foods: a review. Foods 8(2): 54.

Yeu, K., Y. Lee and S.Y. Lee. 2008. Consumer acceptance of an extruded soy-based high-protein breakfast cereal. Journal of Food Science 73(1): S20-S25. https://doi.org/10.1111/j.1750-3841.2007.00601.x 